\title{
Explicating anti-amyloidogenic role of curcumin and piperine via amyloid beta $(A \beta)$ explicit pathway: Recovery and reversal paradigm effects
}

\author{
Aimi Syamima Abdul Manap ${ }^{1}$, Priya Madhavan ${ }^{\text {Corresp., }}{ }^{2}$, Shantini Vijayabalan ${ }^{3}$, Adeline Chia ${ }^{1}$, Koji Fukui ${ }^{\text {Corresp. } 4}$ \\ ${ }^{1}$ School of Biosciences, Faculty of Health and Medical Sciences, Taylor's University, Subang Jaya, Selangor, Malaysia \\ 2 School of Medicine, Faculty of Health and Medical Sciences, Taylor's University, Subang Jaya, Selangor, Malaysia \\ ${ }^{3}$ School of Pharmacy, Faculty of Health and Medical Sciences, Taylor's University, Subang Jaya, Selangor, Malaysia \\ 4 Department of Bioscience and Engineering, College of Systems Engineering and Science, Shibaura Institute of Technology, Saitama, Japan \\ Corresponding Authors: Priya Madhavan, Koji Fukui \\ Email address: Priya.Madhavan@taylors.edu.my, koji@shibaura-it.ac.jp
}

Previously, we reported the synergistic effects of curcumin and piperine in cell cultures as potential anti-cholinesterase and anti-amyloidogenic agents. Due to limited findings on the enrolment of these compounds on epigenetic events in $A D$, we aimed at elucidating the expression profiles of A 442 -induced SH-SY5Y cells using microarray profiling. In this study, an optimized concentration of $35 \mu \mathrm{M}$ of curcumin and piperine in combination was used to treat $A \beta 42$ fibril and high-throughput microarray profiling was performed on the extracted RNA. This was then compared to curcumin and piperine used singularly at $49.11 \mu \mathrm{M}$ and $25 \mu \mathrm{M}$, respectively. Our results demonstrated that in the curcumin treated group, from the top 10 upregulated and top 10 downregulated significantly differentially expressed genes ( $p<0.05$; fold change $\geq 2$ or $\leq-2$ ), there were five upregulated and three downregulated genes involved in the amyloidogenic pathway. While from top 10 upregulated and top 10 downregulated significantly differentially expressed genes $(p<0.05$; fold change $\geq 2$ or $\leq-2$ ) in the piperine treated group, there were four upregulated and three downregulated genes involved in the same pathway, whereas there were five upregulated and two downregulated genes involved $(p<0.05$; fold change $\geq 2$ or $\leq-2$ ) in the curcumin-piperine combined group. Four genes namely GABARAPL1, CTSB, $R A B 5$ and $A K 5$ were expressed significantly in all groups. Other genes such as ITPRI, GSK3B, PPP3CC, ERN1, APH1A, CYCS and CALM2 were novel putative genes that are involved in the pathogenesis of $A D$. We revealed that, curcumin and piperine have displayed their actions against $A \beta$ via the modulation of various mechanistic pathways. Alterations in expression profiles of genes in the neuronal cell model may explain $A \beta$ pathology post-treatment and provide new insights for remedial approaches of a combined treatment using curcumin and piperine. 


\section{Explicating anti-amyloidogenic role of curcumin and piperine via amyloid} 3 beta (A $\beta)$ explicit pathway: Recovery and reversal paradigm effects

4

5

7

8

9

10

11

12

13

14

15

16

Aimi Syamima Abdul Manap ${ }^{1}$, Priya Madhavan ${ }^{2 *}$, Shantini Vijayabalan ${ }^{3}$, Adeline Chia ${ }^{1}$, and Koji Fukui ${ }^{*}$

${ }^{1}$ School of Biosciences, Faculty of Health and Medical Sciences, Taylor's University, Subang Jaya, Selangor, Malaysia

${ }^{2}$ School of Medicine, Faculty of Health and Medical Sciences, Taylor's University, Subang Jaya, Selangor, Malaysia

${ }^{3}$ School of Pharmacy, Faculty of Health and Medical Sciences, Taylor's University, Subang Jaya, Selangor, Malaysia

${ }^{4}$ Department of Bioscience and Engineering, College of Systems Engineering and Science, Shibaura Institute of Technology, Saitama, Japan

\section{* Corresponding Authors:}
1) Dr. Priya Madhavan

Email: Priya.Madhavan@taylors.edu.my

2) Prof Dr Koji Fukui

Email: koji@shibaura-it.ac.jp

\section{Abstract}

Previously, we reported the synergistic effects of curcumin and piperine in cell cultures as potential anti-cholinesterase and anti-amyloidogenic agents. Due to limited findings on the enrolment of these compounds on epigenetic events in $\mathrm{AD}$, we aimed at elucidating the expression profiles of A $\beta 42$-induced SH-SY5Y cells using microarray profiling. In this study, an optimized concentration of $35 \mu \mathrm{M}$ of curcumin and piperine in combination was used to treat A $\beta 42$ fibril and high-throughput microarray profiling was performed on the extracted RNA. This was then compared to curcumin and piperine used singularly at $49.11 \mu \mathrm{M}$ and $25 \mu \mathrm{M}$, respectively. Our results demonstrated that in the curcumin treated group, from the top 10 upregulated and top 10 downregulated significantly differentially expressed genes $(p<0.05$; fold change $\geq 2$ or $\leq-2$ ), there were five upregulated and three downregulated genes involved in the amyloidogenic pathway. While from top 10 upregulated and top 10 downregulated significantly differentially expressed genes ( $<<0.05$; fold change $\geq 2$ or $\leq-2)$ in the piperine treated group, there were four upregulated and three downregulated genes involved in the same pathway, whereas there were five upregulated and two downregulated genes involved $(\mathrm{p}<0.05$; fold change $\geq 2$ or $\leq-2$ ) in the curcumin-piperine combined group. Four genes namely GABARAPL1, $C T S B, R A B 5$ and $A K 5$ were expressed significantly in all groups. Other genes such as ITPRI, 
GSK3B, PPP3CC, ERN1, APH1A, CYCS and CALM2 were novel putative genes that are involved in the pathogenesis of $A D$. We revealed that, curcumin and piperine have displayed their actions against $A \beta$ via the modulation of various mechanistic pathways. Alterations in expression profiles of genes in the neuronal cell model may explain $A \beta$ pathology post-treatment and provide new insights for remedial approaches of a combined treatment using curcumin and piperine.

\section{Introduction}

In the pathogenic cascade of Alzheimer's disease (AD), misfolding, aggregation and deposition of amyloid $\beta(\mathrm{A} \beta)$ peptides in the brain parenchyma and vessel walls lead to severe consequences (Watson et al., 2005). Over the past couple of decades, several studies have highlighted that the $\mathrm{A} \beta$ aggregates as being the core determinants in molecular mechanisms contributing to AD (De Felice et al., 2008; Guglielmotto et al., 2014). In addition, it was proposed that there are different $A \beta$ assemblies, each characterized by different molecular sizes, stability and neurotoxic characteristics (Jin et al., 2011). However, their particular significance to AD pathogenesis is uncertain. Natural products, in which their phytochemicals are known to have numerous beneficial biological neuroprotective effects, are of specific concern to scientists in this era (Bui \& Nguyen, 2017).

We previously demonstrated neuroprotective effects of combined treatment with curcumin and piperine against $\mathrm{A} \beta$ induced degeneration by in silico and in vitro assays (Manap et al., 2019). Curcumin and piperine at $35 \mu \mathrm{M}$ in combination were able to inhibit neurotoxicities, aggregation and disaggregate $A \beta$ fibrils as well as reversed $A \beta$-induced neuronal oxidative stress (Manap et al., 2019). In the present study, we continue our investigation at a molecular level by using high-throughput microarray technology in order to elucidate differences in the gene expression profiles between $\mathrm{AD}$ and treatment groups. Gene expression microarray offers a new tool to address complexity, allowing for overviews of concurrently multiple cellular pathways. The main benefit of the microarray approach is the capacity to explore thousands of genes of interests simultaneously, although low statistical power, elevated false positives or false negatives and unclear reference to functional endpoints often hinder data interpretation.

A large number of expression profiles was examined in the compound-specific group. We observed that genes that were altered and are involved in the mechanism of $A \beta$ appeared in different treatment groups, which signifies that both single and combined compounds exerted neuroprotective activities against the degeneration of A $\beta$. Nevertheless, we found common genes that were differentially expressed in all single and combined treatment with curcumin and piperine. The genes GABARAPL1, CTSB, RAB5 and $A K 5$ had shown to be involved in the intrinsic pathway that modulates the processing of $A \beta$ including macroautophagy and neurite degeneration. In addition, in regards to treatment with a single compound, when focusing on the $\mathrm{A} \beta$ pathway in $\mathrm{AD}$, we revealed an explicit pathway that modulates the expression of $\mathrm{A} \beta$ level and interferes with AD progression. These genes were PICALM, LRP1, CTSB, ADAMTS5, $A P O E$ and $P S E N 1$, which showed to be involved in endothelial A $\beta$ trafficking and disruption in 
81

82

83

84

85

86

87

88

89

90

91

92

93

94

95

96

97

98

99

100

101

102

103

104

105

106

107

108

109

110

111

112

113

114

115

116

117

118

119

120

$\mathrm{A} \beta$ production or rapid $\mathrm{A} \beta$ clearance. Next, we further sought whether the single and combined treatment with curcumin and piperine were able to exert reversal actions on the damages caused by $A \beta$. Interestingly, regardless of whether it was single or combined treatment, we found protective genes which restored synaptic losses caused by A $\beta$ via synaptic modulation, restoration of ubiquitin proteasome system (UPS) pathway, a reversal of neuronal apoptosis and neurite degeneration. We also demonstrated from our study that novel putative genes with limited literature in AD pathologies such as TGIF1, IGFBP3, LBH, ITGA9, SPRY1, VIM, INA, $L Y N, P L C B 4$ and OLFM1. These genes appeared in our top 10 list of upregulated and downregulated genes in single and combined treatment with curcumin and piperine. The results of protein-protein interaction also demonstrated the significant pathways that were involved or potentially involved in the AD pathway, long-term potentiation, TGF-beta signaling pathway, dopaminergic synapse and others. These findings support the hypothesis that single and combined treatment with curcumin and piperine in SH-SY5Y cells exposed to A $\beta$ fibrils may result in differences in expression profiles of genes. Accordingly, a detailed analysis of how these compounds exerted their mechanism of action at the molecular level, the involvement of various potential genes and pathways in AD may lead to a novel finding in AD pathology. The data discussed in this paper have been deposited in NCBI's Gene Expression Omnibus (GEO) and are accessible through GEO Series accession number: GSE143998.

\section{Materials \& Methods}

\section{A $\beta$ fibril preparation}

Synthetic A $\beta 42$ peptide was purchased from American Peptide (Sigma, USA) and prepared following the protocols described previously (Caballero et al., 2016; Tycko, 2018) with some modifications (Figure 1). In brief, the A $\beta 42$ peptide was dissolved to $1 \mathrm{mM}$ in $100 \% 1,1,1,3$, 3, 3-hexafluoro-2-propanol (HFIP, Sigma) and aliquoted in non-siliconized polypropylene vials. The tubes were left in the fume hood overnight to remove HFIP. The traces of HFIP were removed under vacuum (Speed Vac) (Thermo Fisher Scientific, US) on the following day and resuspended in dimethyl sulfoxide (DMSO) to a concentration of $5 \mathrm{mM}$. To form fibrillar conditions, the peptide was diluted to a final concentration of $100 \mu \mathrm{M}$ with $10 \mathrm{mM}$ of acid hydrochloric (HCI) solution and incubated at $4{ }^{\circ} \mathrm{C}$ for $24 \mathrm{hrs}$.

\section{Thioflavin T microscopy staining}

In order to confirm the uptake of $A \beta$ in the cell, Thioflavin $T$ (ThT) fluorescence assay was performed as described previously (Jin et al., 2016). Thioflavin $\mathrm{T}$ is a benzothiazole dye that shows increased fluorescence when binding to amyloid fibrils and is frequently used for the detection of amyloid fibrils (Sulatskaya et al., 2018). Initially, ThT was dissolved in 50\% ethanol to $1 \mathrm{mg} / \mathrm{mL}$ and stored at $4{ }^{\circ} \mathrm{C}$. For live cell imaging, cells treated with $\mathrm{A} \beta$ fibrils were incubated with ThT at $10 \mu \mathrm{g} / \mathrm{mL}$ in DMEM (ATCC ${ }^{\circledR} 30-2002^{\mathrm{TM}}$ ) cell culture media for $30 \mathrm{~min}$ at $37^{\circ} \mathrm{C}$ and examined via live cell fluorescence imaging. The cellular accumulation of ThT was assessed 
121

122

123

124

125

126

127

128

129

130

131

132

133

134

135

136

137

138

139

140

141

142

143

144

145

146

147

148

149

150

151

152

153

154

155

156

157

158

159

160

using Nikon's NIS-Elements fluorescence microscope (Nikon, Tokyo, Japan) and images were processed and analyzed with ImageJ digital image processing (USA).

\section{Immunofluorescence assay}

Immunofluorescence (IFC) assay was performed in order to double confirm the presence and deposition of A $\beta$ fibrils in the cells. SH-SY5Y cells were seeded at a density of $5 \times 10^{4}$ cells $/ \mathrm{ml}$ in $\mu$-slide 8-well IbiTreat chamber slides (Ibidi GmbH, Martinsried, Germany) and incubated at $37^{\circ} \mathrm{C}$ in a humidified $5 \% \mathrm{CO}_{2}$ incubator. After the cells reached $80 \%$ confluency, the cells were treated with $25 \mu \mathrm{M}$ A $\beta$ fibrils for $24 \mathrm{hrs}$. Cells were then washed with PBS three times, fixed with 4\% paraformaldehyde (Aldrich, Steinheim, Germany) for $15 \mathrm{~min}$, and rewashed with PBS three times. Fixed cells were permeabilized with $0.1 \%$ Triton X-100 (Sigma-Aldrich, US), diluted in PBS for 15 min on ice, and washed three times with PBS. Non-specific binding was blocked with $10 \%$ bovine serum albumin (BSA; normal goat serum, AbCam, Cambridge, UK) diluted in PBS $+0.1 \%$ Tween 20 for $1 \mathrm{hr}$ at room temperature. Cells were incubated with mouse monoclonal [DE2B4] to beta amyloid (AB11132, 1:200 dilution, AbCam, Cambridge, UK) diluted in $1 \%$ blocking buffer (PBS $+0.1 \%$ Tween $20-1 \%$ BSA) overnight at $4{ }^{\circ} \mathrm{C}$. Cells were then washed with PBS $+0.1 \%$ Tween 20 three times and incubated with secondary antibodies goat anti-mouse IgG H\&L (Alexa Fluor ${ }^{\circledR} 488$ ) preadsorbed (AB150117, dilution 1:1,000, AbCam, Cambridge, UK) diluted in 1\% blocking buffer (PBS $+0.1 \%$ Tween 20-1\% BSA) for $1 \mathrm{hr}$ at room temperature. After washing three times with PBS $+0.1 \%$ Tween 20 in the dark, cells were incubated with fluoroshield mounting medium with DAPI (AB104139, AbCam, Cambridge, UK) for 5 mins at room temperature in the dark. Finally, cells were ready to be viewed under Nikon's NIS-Elements fluorescence microscope (Nikon, Tokyo, Japan). The images were processed and analyzed with ImageJ digital image processing (USA).

\section{Compound preparation}

The preparation of the optimal concentration of pure curcumin, piperine and their mixtures was performed based on an optimized protocol (Manap et al., 2019).

\section{Cell culture and treatment}

Human Neuroblastoma cells (SH-SY5Y) were purchased from ATCC, USA. The cell lines were maintained in DMEM (ATCC® 30-2002 ${ }^{\mathrm{TM}}$ ), supplemented with 10\% FBS, 5\%

penicillin/streptomycin and incubated at $37^{\circ} \mathrm{C}$ in a humidified $5 \% \mathrm{CO}_{2}$ incubator. Cells at $80 \%$ confluency were seeded into 6 -well plates at a density of $1.2 \times 10^{6}$ cells $/ \mathrm{ml}$. Cells were allowed to adhere overnight at $37^{\circ} \mathrm{C}$ with $5 \% \mathrm{CO}_{2}$. On the following day, cells were treated with individual and combined compounds and incubated for a further $24 \mathrm{hrs}$. There were 4 groups in this study, i.e. one which had only $\mathrm{A} \beta$ (as a control at $25 \mu \mathrm{M}$ ), second group had cells treated for $24 \mathrm{hrs}$ with curcumin $(49.11 \mu \mathrm{M})$ followed by addition of $\mathrm{A} \beta(25 \mu \mathrm{M})$ and incubated for another $24 \mathrm{hrs}$, third group had cells treated for $24 \mathrm{hrs}$ with piperine $(25 \mu \mathrm{M})$ followed by addition of $\mathrm{A} \beta$ ( 25 $\mu \mathrm{M})$ and incubated for another $24 \mathrm{hrs}$ and fourth group had a mixture of curcumin and piperine 
$161(35 \mu \mathrm{M})$, treated for $24 \mathrm{hrs}$ followed by addition of $\mathrm{A} \beta(25 \mu \mathrm{M})$ and incubated for another $24 \mathrm{hrs}$.

162

163

164

165

166

167

168

169

170

171

172

173

174

175

176

177

178

179

180

181

182

183

184

185

186

187

188

189

190

191

192

193

194

195

196

197

198

199

200

These experiments were performed in triplicates.

\section{Total RNA extraction}

Total RNA extraction was performed by using RNApure High-purity Total RNA Rapid Extraction Kit (Bioteke, China) according to the manufacturer's protocol. Total RNA concentration and purity were determined and samples were stored at $-80^{\circ} \mathrm{C}$. All extracted RNA samples were subjected to spectrophotometric measurement (NanoDrop Spectrophotometer ND2000C, Thermo Scientific) and the RNA quality was determined using an Agilent 2100 Bioanalyzer according to the manufacturer's protocol.

\section{Microarray profiling}

A total of twelve RNA samples were processed according to the Applied Biosystems ${ }^{\mathrm{TM}}$ recommended protocol. Briefly, $100 \mathrm{ng}$ of total RNA was reverse transcribed to produce cDNA/mRNA hybrid molecule, which was subsequently used as a template to create doublestranded cDNA. This double-stranded cDNA was then amplified via in vitro transcription (IVT) to produce cRNA. In vitro transcription (IVT) generated cRNA was then purified and subjected to 2nd-cycle single-stranded sense cDNA synthesis which was later fragmented, labeled, and hybridized to Human Clariom S Array for $16 \mathrm{hrs}$ at $45^{\circ} \mathrm{C}$ with rotation at $60 \mathrm{rpm}$. Arrays were then washed and stained using the FS450_0007 fluidics protocol and scanned using an Applied Biosystems $^{\mathrm{TM}}$ GeneChip ${ }^{\mathrm{TM}}$ Scanner $30007 \mathrm{G}$.

\section{Array and data QC}

The scanned images were inspected for hybridization efficiency and CEL files generated from GeneChip Command Console Software were imported into Transcriptome Analysis Console v4.0 software for array QC. RMA normalization was performed on the samples to generate the quality control (QC) metrics that was used to determine data quality. These include, all Probeset mean, background mean (Bgrd_Mean), positive and negative probes (POS vs NEG AUC), bacterial spike controls and Poly-A controls. Protein-protein interaction network analysis visualization and pathway analysis were conducted by using NetworkAnalyst 3.0 (Zhou et al., 2019) and WikiPathways.

\section{Validation of genes by Real-time PCR (qPCR)}

Ten genes were chosen from microarray analysis to be validated by qPCR namely, SYPL1, RAB5, AK5, PICALM, CAP8AP2, APOE, GABARAPL1, PSEN1, CREB1 and ADAMTS5. The reverse transcription kit was used to synthesize the first-strand cDNA (ReverTra Ace qPCR RT Master Mix with gDNA Remover (Code No. FSQ-301). Real-time PCR was carried out using PrimeTime ${ }^{\circledR}$ Gene Expression Master Mix (IDT, USA) at $1 \mathrm{X}$ concentration containing PrimeTime ${ }^{\circledR}$ qPCR primers and 3 pg to $100 \mathrm{ng}$ cDNA template. PrimeTime Standard qPCR Assay (5' - 3' Dye-Quencher Mod: 6-FAM/ZEN/IBFQ) primers (GAPDH and ACTB) were used 
201

202

203

204

205

206

207

208

209

210

211

212

213

214

215

216

217

218

219

220

221

222

223

224

225

226

227

228

229

230

231

232

233

234

235

236

237

238

239

240

as an endogenous control to quantify the target genes. The final volume of each RT-qPCR reaction was $20 \mu \mathrm{L}$, which contained $10 \mu \mathrm{L}$ PrimeTime ${ }^{\circledR}$ Gene Expression Master Mix (IDT, USA), $1 \mu \mathrm{L}$ of each PrimeTime ${ }^{\circledR}$ qPCR Assay primer (IDT, USA), $2 \mu \mathrm{L}$ of diluted cDNA template and $7 \mu \mathrm{L}$ of nuclease free water. PCR cycling protocol was performed by using Eppendorf Mastercycler Realplex2 (Eppendorf, Germany). Cycling included polymerase activation step of $3 \mathrm{~min}$ at $95^{\circ} \mathrm{C}$ was followed by 45 cycles of $5 \mathrm{~s}$ at $95^{\circ} \mathrm{C}$ and $30 \mathrm{~s}$ at $60^{\circ} \mathrm{C}$. Data analysis on expression levels were calculated using the $2^{-\Delta \Delta \mathrm{Ct}}$ comparative CT method (Schmittgen \& Livak, 2008). The means and standard deviations were calculated from experiments performed in triplicate and are presented as the n-fold differences in expression.

\section{Results}

A $\beta 42$ fibrils detection using Thioflavin $\mathbf{T}$ staining We had previously reported on the A $\beta$ inhibition and disaggregation assay of selected compounds by using Thioflavin $\mathrm{T}$ fluorescence assay (Manap et al., 2019). Thioflavin T (ThT) is a small molecule that emits strong fluorescence upon binding to amyloids (Xue et al., 2017). Here, we showed that ThT also works as a dye which stains the $A \beta 42$ fibrils (green fluorescence) in the neuronal cells treated with $A \beta 42$ fibrils for 24 hrs (Figure 2B). While for untreated cells (without the A $\beta 42$ ), we could not see any fluorescence dye being emitted, which confirmed the absence of the fibrils (Figure 2A). We demonstrated that the prepared fibrils were taken up by the cells in vitro upon dissolution.

\section{A $\beta 42$ fibrils detection by immunofluorescence Immunofluorescence studies demonstrated} specific staining of A 342 fibrils (Figure 2D) on SH-SY5Y cells. No staining was observed in SH-SY5Y cells in the absence of the A $\beta 42$ fibrils (Figure 2C; negative control (NC)).

\section{Microarray analysis}

Altered gene expression profiles in multiple comparisons between AD and treatment groups. We obtained gene expression profiles using the Affymetrix Expression Console and Transcriptome Analysis Console (TAC) software from multiple comparison between four groups of cells. These groups were 1) added with $\mathrm{A} \beta$, which is identified as AD group or control (A $\beta$ C); 2) cells treated with curcumin for $24 \mathrm{hrs}$, followed by addition of $A \beta-C u R+A \beta$ group; 3 ) cells treated with piperine, followed by addition of $A \beta-P i p+A \beta$ group and 4) cells treated with combined curcumin and piperine, followed by addition of $\mathrm{A} \beta-\mathrm{CP}+\mathrm{A} \beta$ group. As shown in Figure 3, all samples with no overlapped distribution in the Principal component analysis (PCA) exhibited clear separation between groups $(A \beta-C ; C u R+A \beta ; P i p+A \beta$ and $C P+A \beta)$ by hierarchical clustering of their expression profiles (Figure 4). The mapping of expression values to intensities was depicted by color-bar created by the range of values in their respectiveconditions, i.e.-red for up-regulation and blue for down-regulation of genes. 
241 By analyzing expression profiles of these samples using TAC software, we found that from 24221,448 total number of genes altered, 9951 genes passed the filter criteria where, 1723 genes 243 were up-regulated and 1481 genes were down-regulated in $[\mathrm{CuR}+\mathrm{A} \beta]$ vs. $\mathrm{A} \beta$ group; whereas 2442028 genes were up-regulated and 1635 genes were down-regulated in [Pip $+A \beta]$ vs. A $\beta$ group; 245 and 1210 genes were up-regulated, 1904 genes were down-regulated in $[\mathrm{CP}+\mathrm{A} \beta]$ vs. $\mathrm{A} \beta$ group 246 (filter criteria: ANOVA: $\mathrm{P}<0.05$, a lower bi-weight average signal $(\log 2)>6.64$, a fold change $\geq$ 2472 or $\leq-2$ (Table 1). Top 20 differentially expressed genes for each comparison are shown in 248 Tables 2,3 and 4.

249

250 Individual treatment $(C u R+A \beta$ vs. $A \beta)$ :

251

252

253

254

255

256

257

258

259

260

261

262

263

264

265

266

267

268

269

270

271

272

273

274

275

276

277

278

279

280

From total 1723 upregulated and 1481 downregulated genes differentially expressed in $\mathrm{CuR}+$ $\mathrm{A} \beta$ group, we presented the top 10 upregulated and top 10 downregulated genes that were significantly expressed (Table 2). We had identified the top 10 upregulated genes as TGIF1, GABARAPL1, SYPL1, PICALMS, CTSB, IGFBP3, FSTL1, LBH, GABRA4 and CASP8AP2, while the top 10 downregulated genes were ITGA9, AK5, SPRY1, APOE4, VIM, VAMP1, $R A B 5 B, S C N 3 B, L F R 5$ and $L C O R$. We sought to evaluate the involvement of these genes in A $\beta$ pathway and found that from literatures, i.e. SYPL1 in synaptic modulation, PICALM in endothelial A $\beta$ trafficking mechanism, $C T S B$ in A $\beta$ degrading enzyme, $A P O E$ in APP processing, CASP8AP2 in apoptosis, AK5 in neurite degeneration whereas GABARAPL1 and $R A B 5 B$ were involved in macroautophagy.

\section{Individual treatment (Pip $+A \beta$ vs. $A \beta)$ :}

From the total 2028 upregulated and 1635 downregulated genes differentially expressed in Pip + $A \beta$ group, we presented the top 10 upregulated and top 10 downregulated genes that were significantly expressed in Table 3. We had identified the top 10 upregulated genes as GABARAPL1, CUL3, CASP8AP2, AP3B2, CREB1, DCTD, GPC3, CTSB, FSTL1 and GABRA4. While the top 10 downregulated genes were INA, RAB5B, OLFM1, HEATR5A, VAMP1, PSEN1, $A K 5, B M F, L A M P 1$ and $L Y N$. We sought to evaluate the involvement of these genes in $\mathrm{A} \beta$ pathway and found that from literatures, $C R E B 1$ involved in Ubiquitin proteasome system (UPS) pathway, CTSB in AB degrading enzyme, PSEN1 in APP processing, CASP8AP2 and BMF in apoptosis whereas GABARAPL1 and RAB5B are involved in macroautophagy.

\section{Combined treatment $(C P+A \beta$ vs. $A \beta)$ :}

From a total of 1210 upregulated and 1904 downregulated genes differentially expressed in the $\mathrm{CP}+\mathrm{A} \beta$ group, we presented the top 10 upregulated and top 10 downregulated genes that were significantly expressed in Table 4. We had identified the top 10 upregulated genes as GABARAPL1, FADD, LRP1, VAPB, AP3B2, CTSB, CUL3, ADAMTS5, NTRK3 and TGIF1, while the top 10 downregulated genes were PLCB4, LRG5, TPMT, VIM, OLFM1, ND3, RAB5, $A K 5 L Y N$ and INA. We sought to evaluate the involvement of these genes in A $\beta$ pathway and found that from literatures, ADAMTS5 and CTSB were involved in A $\beta$ degrading enzyme, LRP1

PeerJ reviewing PDF | (2020:02:45631:2:1:NEW 24 Aug 2020) 
281

282

283

284

285

286

287

288

289

290

291

292

293

294

295

296

297

298

299

300

301

302

303

304

305

306

307

308

309

310

311

312

313

314

315

316

317

318

319

320

in endothelial A $\beta$ trafficking, $F A D D$ in apoptosis, $A K 5$ in neurite degeneration whereas GABARAPL1 and RAB5B were involved in macroautophagy.

We then compared the genes among the three groups, and found that all groups shared a total of 1045 genes $(16.9 \%)$ that were differentially altered in the comparison between $\mathrm{AD}$ group $(\mathrm{A} \beta-\mathrm{C})$ and individual (curcumin and piperine) as well as in combined treatment (combined curcumin and piperine) (Figure 5). A top 20 differentially expressed genes were shared in these three groups as shown in Table 5. Protein-protein interaction network was performed on the top 20 (Figure 6A) significant differentially expressed genes (DEGs) that are listed in Table 5 by using Network Analyst Software 3.0. While Table 6 showed the top 20 most significant pathways that are involved and potentially involved in AD.

\section{The expression level of commonly altered genes in treatment and control groups increase} Alzheimer progression through Alzheimer's disease pathway.

Among the total genes significantly differentially expressed in each group (3204 genes in [CuR + $A \beta]$ vs. $A \beta, 3663$ genes in [Pip $+A \beta]$ vs. $A \beta$ and 3114 genes $[C P+A \beta]$ vs. $A \beta)$, only 25 genes have been identified to be involved in AD pathway, regardless of $\mathrm{A} \beta$ specific pathways, characterized by WikiPathways (Table 7). However, only 6 genes were shared among the three comparisons identified as APOE, FADD, LRP1, PLCB3, PLCB4 and GRIN2A (shown in bold). $A P O E, F A D D, L R P 1$ and PLCB3 appeared to be up-regulated in all three comparisons while PLCB4 and GRIN2A were downregulated. Protein-protein interaction network was performed on top 25 (Figure 6B) and top 8 (Figure 6C) significantly differentially expressed genes (DEGs) that are listed in Table 7 by using Network Analyst Software 3.0.

Gene expression changes validated by $q P C R$

The results obtained from qPCR confirmed the expression changes of the selected genes from microarray (Figure 7).

\section{Discussion}

The present study was performed to assess the anti-amyloidogenic role of individual and combined curcumin and piperine. Thioflavin T microscopy staining and immunofluorescence confirmed the uptake of A $\beta$ in SH-SY5Y cells. From the microarray analysis, we demonstrated for the first time that these compounds exhibited their actions against $A \beta$ via modulation of various mechanistic pathways that are responsible either via production or clearance of $A \beta$. In addition, it has been shown that the neuroprotective effects of these compounds on degeneration have been induced by A $\beta$ such as synaptic impairment, degradation of the ubiquitin proteasome system (UPS), apoptosis, and neurite degeneration as discussed in the following sections . Protein-protein interaction (PPI) has shown that various networks of interactions tend to be potentially involved in AD. Although there are some limitations of microarray data which often hinder data interpretation, the key advantage of the microarray provides a new method for tackling ambiguity, enabling simultaneous overviews of several cellular pathways. . 
322

323

324

325

326

327

328

329

330

331

332

333

334

335

336

337

338

339

340

341

342

343

344

345

346

347

348

349

350

351

352

353

354

355

356

357

358

359

360

Modulation of macroautophagy process was observed in all single and combined treatment of curcumin and piperine

A key determinant of cell survival and longevity is macroautophagy, a lysosomal pathway for organelles turnover and long-lived proteins. Previous study by Yu et al. (2005) showed that, neuronal macroautophagy was induced early in $\mathrm{AD}$ and right before $\mathrm{A} \beta$ deposits extracellularly in the mouse model of presenilin (PS) $1 / \mathrm{A} \beta$ precursor protein pathology/pathway (APP) (Yu et al., 2005). From our findings, we found that expression of GABARAP and RAB5 genes were altered in all three groups indicating protective roles of the compounds against $A \beta$ toxicities, by modulating the macroautophagy process.

Gamma-aminobutyric acid receptor-associated proteins (GABARAPs; GABARAP, GABARAP-L1, GABARAP-L2), ubiquitin-like proteins that are covalently conjugated to phosphatidylethanolamine (PE) on autophagosomal membranes promote the formation, elongation and maturation of autophagosomes (Kabeya et al., 2004; Nakatogawa, 2013). This $G A B A$ receptor modulators have been explored in $\mathrm{AD}$ as a prospective therapeutic approach. Our data indicates that upregulation of GABARAPL1 was caused by the treatment of curcumin, piperine singularly and combination of these (Figure 8), whereas it was downregulated in the control group (A $\beta$ without any treatment). These findings are in agreement with earlier reports on the effects of $A \beta$ at inhibitory synapses. Ulrich (2015) investigated the impact of acute A $\beta 1$ 42 application on GABAergic synaptic transmission in rat somatosensory cortex in vitro (Ulrich, 2015). He found in his study that, with intracellular applications of $\mathrm{p} 4$, a blocker of internalization of the GABA(A) receptor, the A $\beta$-induced IPSC reduction could be avoided, which may conclude that $A \beta$ weakens synaptic inhibition via downregulation of GABA(A) receptors (Ulrich, 2015). Moreover, $G A B A$ also found to suppress uptake of $A \beta$ in neurons via the receptor for advanced glycation of end-products (Sun et al., 2012). RAB5 is a member of the RAS oncogene family (Nakhaei-Rad et al., 2018). The small GTPases Rab are important intracellular membrane trafficking regulators, ranging from transport vesicles to membrane fusion $R A B 5$ endosomes are the main sites for $\beta$-secretase (Grbovic et al., 2003). Sustained $R A B 5$ activation promotes APP cleavage and builds toxic beta-CTFs ( $\beta C T F s)$ and A $\beta$ species. In turn, intense $\beta C T F$ s and $A \beta$ also enhance active types of $R A B 5$, leading in enlarged endosomes and accelerated amyloidogenic APP processing (Nixon, 2017). Downregulation of this $R A B 5$ by curcumin, piperine and $\mathrm{CP}$ group may indicate crucial inhibition of $\beta$-secretase activity by declining APP cleavage and preventing buildup of toxic A $\beta$ (Figure 8).

\section{Modulation of endothelial A $\beta$ trafficking by PICALM and LRP1 through transcytosis} PICALM has been remarkable as robustly validated genetic risk factor for AD. PICALM is among the highly abundant clathrin adaptors in clathrin-coated endocytic vesicles and regulates endocytic processes in presynaptic active neuronal zones (Blondeau et al., 2004; Koo et al., 2011). PICALM regulates the formation of A $\beta$ through endocytosis of APP and $\gamma$-secretase, presumably in neurons (Figure 9). Other scientists also noted that PICALM plays a significant

PeerJ reviewing PDF | (2020:02:45631:2:1:NEW 24 Aug 2020) 
361

362

363

364

365

366

367

368

369

370

371

372

373

374

375

376

377

378

379

380

381

382

383

384

385

386

387

388

389

390

391

392

393

394

395

396

397

398

399

400

role in tau clearance and autophagy, implying that PICALM is a multifunctional protein (Moreau et al., 2015). We found in our study that PICALM expression level was downregulated in $\mathrm{A} \beta$ group while upregulated in the group treated with curcumin. While PICALM expression was not observed in the group treated with piperine and in CP. (Figure 8). Our finding coincides with the previously reported studies where reduced expression of PICALM was observed in AD and murine brain endothelium associated $A \beta$ pathology and cognitive decline (Zhao et al., 2015). In addition, they found that reduced PICALM level impaired $A \beta$ clearance across the murine bloodbrain barrier (BBB) and enhanced $\mathrm{A} \beta$ pathology in a way reversible through endothelial reexpression of PICALM (Zhao et al., 2015). Furthermore, we demonstrated that the expression level of the $L R P 1$ gene was upregulated in the group treated with CP (Figure 8). The lowdensity lipoprotein related protein $(L R P)$, a constituent of the low-density lipoprotein receptor $(L D L R)$ family, is a multi-ligand receptor of which its physiological functions are performed by ligand endocytosis and by activation of multiple signal transduction pathways (Herz \& Strickland, 2001). Previous study reported that extracellular A $\beta$ must bind to low-density lipoprotein-related protein 1 ( $L R P 1)$ in capillary endothelial cells of the brain to be transported through the cell to the bloodstream (Deane et al., 2004). Another study by Zhao et al., (2015) reported that PICALM was attached to the $A \beta / L R P 1$ complex within 30 seconds of the addition of A $\beta$ to the basolateral membrane (Zhao et al., 2015). Upregulation of both PICALM and LRPI in our treatment groups may provide a significant finding on the modulatory approach of these compounds on the degeneration of toxic $A \beta$ via facilitating transcytosis of $A \beta$.

\section{Disruption in $A \beta$ production or rapid $A \beta$ clearance mechanistic pathways against $A \beta$} degeneration

The fundamental strategy to degenerate toxic $A \beta$ was to stop, inhibit or disrupt the production of $A \beta$ at an early point, before $A \beta$ has been circulated into the neurons. Thus, the detrimental effects of the $A \beta$ can be abolished at the early onset of the disease. Otherwise, an alternative strategy was to facilitate $A \beta$ clearance through $B B B$, thus flushing off this toxic $A \beta$ protein. We showed from our study that, curcumin and piperine were able to interfere with either of these two pathways-at the initial or end stages, through modulation of the expression of genes that are responsible at various stages of the pathway.

i. $\quad$ Upregulation of $A \beta$ degrading enzyme

Over the past century, enzyme-mediated degradation of $A \beta$ has gained much attention. Many enzymes are capable of cleaving full-length $A \beta$ in vitro, generating fragments that are generally less neurotoxic, less likely to aggregate and more easily cleared than $A \beta$ in full length (Hu et al., 2001). We demonstrated that, CTSB gene, which produces $A \beta$ degrading protease (Miners et al., 2011) was downregulated in $A \beta$ group and upregulated in all treatment groups (Figure 8). This gene encodes a member of the peptidase family $\mathrm{C} 1$. Alternative splicing of this gene results in various transcript forms (Jevnikar \& Kos, 2009). Previous research showed that CTSB A $\beta_{1-42}$ cleavage produces $C$-terminally truncated peptides $\left(A \beta 1_{-40}, A \beta_{1-38}\right.$, and $\left.A \beta_{1-33}\right)$, all of which are less toxic and less fibrillogenic than full-length $A \beta_{1-42}$ (Mueller-Steiner et al., 2006). The 
401 upregulation of this gene observed in our experimental data may indicate favorable mechanism

402 of these compounds on $C T S B$ gene expression by increasing the activity of the enzyme and

403

404

405

406

407

408

409

410

411

412

413

414

415

416

417

418

419

420

421

422

423

424

425

426

427

428

429

430

431

432

433

434

435

436

437

438

439

440 elevating clearance of $A \beta$, thus provide therapeutic potential in $A D$.

On the other hand, we also observed that, besides the CTSB gene, ADAMTS5 gene was also upregulated in the group treated with combined curcumin-piperine (Figure 8). The expression of this gene did not appear in the group treated with curcumin and piperine singularly. The proteins A-like disintegrin and metalloproteinase (MMP) with motifs of thrombospondin (ADAMTS) were recognized as secreted protease enzymes, some of which may bind to the extracellular matrix (ECM) (Porter et al., 2005). The crucial substrates of the enzymes are the aggregating chondroitin sulphate proteoglycans (CSPGs), including brevican, versican and aggrecan, recognized as the CNS's complete integral parts of the ECM (Porter et al., 2005).. ADAMTS expression was discovered in the central nervous system (CNS) after various extensive research and is known to change in disease circumstances (Miguel, Pollak \& Lubec, 2005; Haddock et al., 2006; Gottschall \& Howell, 2015). The downregulation of ADAMTS5 expression level in our $\mathrm{A} \beta$ group data was supported by previous study which demonstrated that ADAMTS4 and ADAMTS5 expressions were slightly under-expressed in case of $\mathrm{AD}$ which indicated the deficiency in the elimination of ECM in patients, which ultimately resulted in the accumulation of undesirable ECM compounds over time (Pehlivan et al., 2016). Likewise, increase expression of ADAMTS5 from the combined treatment may assist in elevating the deterioration of ECM constituents, including $A \beta$ senile plaque (Pekny \& Nilsson, 2005), which in turn, might aid recovery by the elimination of the CSPGs.

\section{ii. Inhibition of neurotoxic $A \beta$ aggregation and plaque deposition}

Apolipoprotein $\mathrm{E}(A P O E)$ gene polymorphism is a significant risk determinant for late-onset $\mathrm{AD}$ in patients, whose symptoms develop only after age 65 (Lambert et al., 2013). Of the three main types of $A P O E, A P O E^{*} 4$ is correlated with an increased risk (Stocker et al., 2018) and $A P O E^{*} 2$ is linked with a reduced risk (Escott-Price et al., 2019) of AD compared to the common $A P O E^{*} \varepsilon 3$ allele. Assembling proof indicates that the isoform $A P O E^{*} \& 4$ drives amyloid pathology and impairs various aspects of normal brain function, increasing the risk of AD (Fernandez et al., 2019; Safieh, Korczyn \& Michaelson, 2019). We demonstrated that APOE gene expression was upregulated in the group treated with $A \beta$ alone, which may increase the risk for AD. Parallel to our findings, it was reported previously that HEK293 cell-derived APOE induced transcription of APP and generation of A $\beta$ in human embryonic stem cells and iPSCderived neurons (Huang et al., 2018). The effects of this is depended on isoforms, with $A P O E^{*} \varepsilon 4$ more profoundly accelerating $A \beta$ production than other isoforms (Huang et al., 2018). Moreover, $\mathrm{A} \beta$ secretion in human iPSC-derived neurons carrying $A P O E^{*} \& 4$ is significantly higher than in those with $A P O E^{*}{ }_{\varepsilon}$, likely due to increased transcription of APP (Wang et al., 2018b). Due to the different allele specificity that increase the risk of AD, the upregulation of the APOE gene expression in our result might be contributed by the allele specificity of the gene which may be caused by $A P O E^{*} \& 4$ allele. Further studies are needed in order to prove the allele specificity of the gene. Down regulation of APOE gene- in the group treated with curcumin may suggest 
441 inhibitory effects of this compound against APOE induced production of A $\beta$ through suppression 442 of transcriptional and APP processing (Figure 8).

443 Another interesting finding in conjunction with the degenerating effects of $A \beta$ revealed 444 that Presenilin 1 (PSEN1) expression was down-regulated in the group treated with piperine. In 445 regards to the formation of $A \beta$, sequential cleavage of APP by $\beta$-secretase $(B A C E-1)$ and $\gamma$ 446 secretase resulted in A $\beta 1-40$ and $A \beta 1-42$, which is widely perceived as neurotoxic (Tan \& 447 Gleeson, 2019). The gene PSEN1 is presumably the catalytic core of the enzyme and is one of 448 the components of $\gamma$-secretase (Maia \& Sousa, 2019). Mutations in PSEN1 gene are associated 449 with some incidents of early-onset familial AD (Ghani et al., 2018). Presenilin 1 is a substrate for 450 glycogen synthase kinase-3 $\beta$ (GSK-3 $\beta$ ) that can phosphorylate PSEN1, thereby modifying its 451 activity (Chu \& Liu, 2018). Increased GSK-3 $\beta$ expression was associated with AD as well. For 452 example, mutations in mice that encodes these genes have resulted in elevated levels of $\mathrm{A} \beta$ 453 deposition, as well as learning and memory impairments (Myers \& McGonigle, 2019; Zhao et 454 al., 2019). We found that for the first time, piperine does appear to affect the activity of $\gamma$ 455 secretase, by decreasing the expression of the catalytic component of the enzyme PSEN1 (Figure 8). This mechanism may result from the inhibition of GSK-3 $\beta$, which generally phosphorylates PSEN1 to stimulate $\gamma$-secretase (Hamann, 2018). Therefore, it can be suggested that inhibition of

459

460

461

462

463

464

465

466

467

468

469

470

471

472

473

474

475

476

477

478

479

480 the APP maturation process could account for the observed decrease in A $\beta$ by interrupting the pathway that leads to its production.

\section{Neuroprotective effects of curcumin and piperine against neurotoxicity}

We discussed earlier in the previous section from our data that curcumin and piperine exerted their effects against $A \beta$ by modulating the pathway of $A \beta$. However, if the damage had already begun in the brain, the strategy was to prevent it from progressing rapidly. Pivotal roles of these compounds against the degeneration effects caused by $\mathrm{A} \beta$ can be explained below based on the changes in the gene expression levels.

\section{$i$. Restoration of synaptic loss via synaptic modulation}

$\mathrm{A} \beta$ accumulation and the loss of synapses are the main notable features of AD. Numerous research demonstrates a decrease in synapse-related proteins, with one of the most robust synaptophysin or synaptophysin-like 1 (SYN, SYPL1) genes being downregulated (Ozcelik et al., 1990; Yang, Frendo-Cumbo \& MacPherson, 2019). Synaptophysin is an essential glycoprotein membrane of $38 \mathrm{kDa}$ originally derived from presynaptic vesicles (Wiedenmann \& Franke, 1985). Our results showed the downregulation of $S Y N$ gene in $A \beta$ group which coincides with previous reports (Ozcelik et al., 1990; Reddy et al., 2005). A $\beta$ peptides interfere with both preand post-synaptic mechanisms of glutamatergic neurotransmission (Lacor et al., 2004) The presence of $A \beta$ peptides located in the spines of dissociated hippocampal cells originally proposed that it could influence post-synaptic functions directly. This resulted in the assumption that the impacts of $A \beta$ peptides in synaptic dysfunction might result from an agonist action of NMDARs (Molnár et al., 2004). This theory was further endorsed by the results that A $\beta$ was located in the brains of AD patients at the post-synaptic ends (Koffie et al., 2009). Increased 
481

482

483

484

485

486

487

488

489

490

491

492

493

494

495

496

497

498

499

500

501

502

503

504

505

506

507

508

509

510

511

512

513

514

515

516

517

518

519

520

expression of SYPL1 gene in the cells treated with curcumin, suggested the protective role of this compound by reversing the effect of $\mathrm{A} \beta$ on synaptic loss (Figure 8).

ii. $\quad$ Restoration of ubiquitin proteasome system (UPS) pathway

The ubiquitin-proteasome system (UPS) is a key mechanism of the degradation of intracellular proteins. Impairment of the UPS has been linked in the pathogenesis of a broad range of neurodegenerative disorders, such as Alzheimer, Parkinson, and Huntington (Gong et al., 2006). The effect of the UPS in these diseases may be associated with deficiencies in the clearance of misfolded proteins that lead to intracellular protein aggregation, cytotoxicity and cell death. Ubiquitinated proteins are identified in oligomeric $A \beta$ plaques and neurofibrillary tangles, and a mutation in the ubiquitin $(\mathrm{Ub})$ mutant protein $\left(\mathrm{Ubb}^{+1}\right)$ causes neuronal deterioration and is connected to AD and impairment of spatial memory (Van Leeuwen, Hol \& Fischer, 2006). In neurons, the signaling pathway of cyclic adenosine 3', 5'-monophosphate (cAMP)cAMP-dependent protein kinase (PKA)-cAMP response element-binding protein $(C R E B)$ is involved in synaptic plasticity and cognitive function and is regulated by UPS by degrading the regulatory subunit of PKA (Vitolo et al., 2002). PKA activation and rise in $C R E B$ phosphorylation are crucial for the development of stable long-term memory (Chain, Schwartz \& Hegde, 1999; Fioravante \& Byrne, 2011). We demonstrated from our study that the expression of $C R E B$ was downregulated in the group treated with $A \beta$. This finding was supported by a previous study where this signaling pathway has been shown to be impaired by $A \beta$ in cultivated cells or brain slices treated with oligomeric $A \beta$ and in vivo as demonstrated by mouse models of transgenic AD (Vitolo et al., 2002; Smith et al., 2009). Whereas, the level of CREB expression was higher in the group treated with piperine, suggesting the protective role of this compound against A $\beta$-induced impairment via UPS pathway (Figure 8).

iii. $\quad$ Programmed cell death as a defense against neuronal insults Several studies have shown that apoptotic mechanisms are activated within the AD brain. Apoptosis is characterized by blebbing of plasma membranes, nuclear condensation and fragmentation of DNA (Metzstein, Stanfield \& Horvitz, 1998) and is triggered by a family of aspartate proteases, known as caspases, which are activated by proteolysis from pro-caspases to their active form (Thornberry \& Lazebnik, 1998). There are currently two significant apoptosis pathways: the death-receptor pathway where caspase- 8 plays a crucial initiator role and the mitochondrial pathway incorporating oxidative stress and caspase- 9 activation. Caspase- 8 is the wide characterized initiator caspase, which was involved in the receptor cell death program of Fas / CD95 or tumor necrosis factor (TNF). In this context, caspase-8 is considered to be the most apical member of the caspase family recruited by adapter proteins (e.g., Fas associated death domain, FADD) and converted by autoproteolysis into an active form (Muzio et al., 1996). Cleavage of Caspase- 8 results in two 11 and $18 \mathrm{kDa}$ active fragments, both which represent the enzyme's activated form. In turn, it is believed that Caspase- 8 triggers downstream caspases, mainly caspase-3, frequently referred to as the executioner caspase. We revealed from our study that the expression level of Caspase 8 associated protein 2 (CASP8AP2) was upregulated in the group treated with curcumin and piperine, while $F A D D$ level was upregulated in a combined 
521 therapy (Figure 8). Our significant findings speculate that the upregulation of these genes was 522 due to a programmed cell death mechanism as a defense against neuronal damage insults caused 523 by $\mathrm{A} \beta$, such as neuroinflammation, neurotoxicity, and altered neurotransmitter release (Panza et 524 al., 2019). These findings indicate that Fibrillar $A \beta$ may induce neuronal cell death correlated 525 with $\mathrm{AD}$ by triggering apoptosis after death-receptor cross-linking and concomitant caspase- 8 526 and caspase-3 activation.

527

iv. Reversal of $A \beta$-induced neuronal apoptosis

528 In contrast to the above mentioned activated programmed cell death in response to $A \beta$-induced 529 neuronal insults, we found that, one of the pro-apoptotic gene known as Bcl-2 modifying factor $530(B M F)$ was down regulated in the group treated with piperine (Figure 8). The pro-apoptotic Bcl531

532 2 homology 3 domain only (BH3-only) proteins are core regulators of cell death in multiple physiological and pathological conditions, including AD. The modifying factor of $\mathrm{Bcl}-2(B M F)$

533

534

535

536

537

538

539

540

541

542

543

544

545

546

547

548

549

550

551

552

553

554

555

556

557

558

559

560

is one of those BH3-only proteins involved in the regulation of apoptosis (Akhter et al., 2018) through the mitochondria pathway. Our significant finding on reversal effect of piperine against $\mathrm{A} \beta$-induced neuronal insults via modulation of $B M F$ was in parallel with the previous study which reported that there was upregulation of $B M F$ resulted in cell death and the BMF knockdown proved that it had protected the neurons against death evoked by $A \beta$ or NGF deprivation (Akhter et al., 2018).

v. Reversal of $A \beta$-induced neurite degeneration

We demonstrated from our study that Adenylate kinases 5 (AK5) are down-regulated following in vitro $\mathrm{A} \beta$ exposure in groups treated with single and combination of curcumin and piperine. (Figure 8). While, this gene was noted for upregulation in the $A \beta$ control group (without any treatment). This finding coincided with the previous study reported by Moon et al. 2017 which showed that AK5 mediated neurite degeneration by the reactive oxygen species (ROS). (Moon et al., 2017). They found that the $A K 5$ expression level was significantly upregulated in the primary neuronal cells exposed to $\mathrm{A} \beta$ and hydrogen peroxide $\left(\mathrm{H}_{2} \mathrm{O}_{2}\right)$. The $A K 5$ gene plays a primary role in the metabolism of nucleotide through nucleotide phosphoryl exchange. There were limited findings on $A K 5$ gene and its involvement in $\mathrm{AD}$, which may provide novel insights on the reversal mechanism of a potential compound of curcumin and piperine combating this degeneration effects.

Novel putative genes involved in AD pathway provide an opportunistic approach for future study.

We demonstrated in our data, regardless of emphasizing the major extrinsic $A \beta$ pathway, we identified 25 differentially expressed genes that are involved in the AD pathway. Out of these 25, six genes that were altered in all groups were $A P O E, F A D D, L R P 1, P L C B 3, P L C B 4$ and GRIN2A. Genes $A P O E$, FADD, LRP1 and $P L C B 3$ appeared to be up-regulated in all three groups while PLCB4 and GRIN2A were downregulated. We observed that PLCB3 and GRIN2A genes were the genes that have limited supporting works of literature in AD. Furthermore, we suggest other novel putative genes such as ITPR1, GSK3B, PPP3CC, ERN1, APH1A, CYCS and CALM2

PeerJ reviewing PDF | (2020:02:45631:2:1:NEW 24 Aug 2020) 
561 to be investigated in the future. Interestingly, we revealed in the network analysis that genes in 562 AD pathway such as calcium signaling pathway, neuroactive ligand-receptor interaction, long563 term potentiation, apoptosis, cholinergic synapse and inflammation were also involved. These 564 network interactions and biological pathways provide an insight and opportunistic approach to

565 further investigate the causal role in $\mathrm{AD}$, and the link between different pathways.

566

\section{Conclusions}

568 We confirmed in our data that curcumin and piperine exerted their effects against $A \beta$ by 569 modulation of various intrinsic pathways. As demonstrated in our previous publication, we 570 provided evidence in which the synergistic effect of curcumin and piperine was able to inhibit 571 and reverse the detrimental effects caused by A $\beta$. In the present study, we observed that in the

572

573 groups treated with either single or combined compounds, all of them showed neuroprotective effects against $A \beta$, which supported previous literatures on curcumin and piperine in cognitive

574 abilities studied individually.

575

576

577

578

579

580

581

582

583

584

585

586

587

588

589

590

We successfully characterized potential genes that appeared to be involved in $A \beta$ pathway and interestingly, our data provided evidence of the anti-amyloidogenic potential of curcumin and piperine against $A \beta$. In a future perspective, it is relevant to implement this data in primary hippocampal neurons, or current approach, three dimensional model, which offers better insights towards changes in $\mathrm{A} \beta$ as progression into $\mathrm{AD}$. In addition, healthy brain cells can be included as a control to identify gene expression related to neurodegeneration and dementia. The significance of our finding was that these data may help to understand the fundamentals of disease heterogeneity at a molecular level and provide a basis before experimenting in in vivo models. Furthermore, the next step from this finding is to either inhibit or mimic selected potential genes to further investigate the changes or effects from a downstream level, considering appropriate therapies based on recognition of different target phenotypes.

\section{Acknowledgements}

We would like to thank Taylor's University for the support, assistance and facilities provided during the research and Shibaura Institute of Technology, Japan (SIT) for their support and funding this publication

591

\section{References}

593 Abid NB, Naseer MI, Kim MO. 2019. Comparative Gene-Expression Analysis of Alzheimer's Disease 20:1219. 
596 Akhter R, Saleem S, Saha A, Biswas SC. 2018. The pro-apoptotic protein Bmf co-operates with Bim and

597

598

599

600

601

602

603

604

605

606

607

608

609

610

611

612

613

614

615

616

617

618

619

620
Puma in neuron death induced by $\beta$-amyloid or NGF deprivation. Molecular and Cellular Neuroscience 88:249-257.

Andreoli V, De Marco EV, Trecroci F, Cittadella R, Di Palma G, Gambardella A. 2014. Potential involvement of GRIN2B encoding the NMDA receptor subunit NR2B in the spectrum of Alzheimer's disease. Journal of Neural Transmission 121:533-542.

Blondeau F, Ritter B, Allaire PD, Wasiak S, Girard M, Hussain NK, Angers A, Legendre-Guillemin V, Roy L, Boismenu D. 2004. Tandem MS analysis of brain clathrin-coated vesicles reveals their critical involvement in synaptic vesicle recycling. Proceedings of the National Academy of Sciences 101:3833-3838.

Bui TT, Nguyen TH. 2017. Natural product for the treatment of Alzheimer's disease. Journal of basic and clinical physiology and pharmacology 28:413-423.

Caballero E, Calvo-Rodríguez M, Gonzalo-Ruiz A, Villalobos C, Núñez L. 2016. A new procedure for amyloid $\beta$ oligomers preparation enables the unambiguous testing of their effects on cytosolic and mitochondrial $\mathrm{Ca} 2+$ entry and cell death in primary neurons. Neuroscience letters 612:66-73.

Chain DG, Schwartz JH, Hegde AN. 1999. Ubiquitin-mediated proteolysis in learning and memory. Molecular neurobiology 20:125-142.

Chen S-C, Lu G, Chan C-Y, Chen Y, Wang H, Yew DT-W, Feng Z-T, Kung H-F. 2010. Microarray profile of brain aging-related genes in the frontal cortex of SAMP8. Journal of molecular neuroscience 41:12-16.

Chu D, Liu F. 2018. Pathological changes of tau related to Alzheimer's Disease. ACS chemical neuroscience 10:931-944.

Cribbs D, Pike C, Weinstein S, Velazquez P, Cotman C. 1997. $\beta$-Amyloid stereoisomers exhibit similar structural and biological properties: implications for mechanisms of toxicity. $J$ Biol Chem 272:7431.

Peer) reviewing PDF | (2020:02:45631:2:1:NEW 24 Aug 2020) 
621 De Felice FG, Wu D, Lambert MP, Fernandez SJ, Velasco PT, Lacor PN, Bigio EH, Jerecic J, Acton PJ, 622 Shughrue PJ. 2008. Alzheimer's disease-type neuronal tau hyperphosphorylation induced by A $\beta$ $623 \quad$ oligomers. Neurobiology of aging 29:1334-1347.

624 Deane R, Wu Z, Sagare A, Davis J, Du Yan S, Hamm K, Xu F, Parisi M, LaRue B, Hu HW. 2004.

625 LRP/amyloid $\beta$-peptide interaction mediates differential brain efflux of A $\beta$ isoforms. Neuron $626 \quad 43: 333-344$.

627 Duran-Aniotz C, Cornejo VH, Espinoza S, Ardiles ÁO, Medinas DB, Salazar C, Foley A, Gajardo I, 628 Thielen P, Iwawaki T. 2017. IRE1 signaling exacerbates Alzheimer's disease pathogenesis. Acta 629 neuropathologica 134:489-506.

630 Endele S, Rosenberger G, Geider K, Popp B, Tamer C, Stefanova I, Milh M, Kortüm F, Fritsch A, 631 Pientka FK. 2010. Mutations in GRIN2A and GRIN2B encoding regulatory subunits of NMDA 632 receptors cause variable neurodevelopmental phenotypes. Nature genetics 42:1021.

633 Escott-Price V, Myers A, Huentelman M, Shoai M, Hardy J. 2019. Polygenic risk score analysis of 634 Alzheimer's disease in cases without APOE4 or APOE2 alleles. The journal of prevention of 635 Alzheimer's disease 6:16-19.

636 Fernandez CG, Hamby ME, McReynolds ML, Ray WJ. 2019. The role of APOE4 in disrupting the 637 homeostatic functions of astrocytes and microglia in aging and Alzheimer's disease. Frontiers in 638 aging neuroscience 11:14.

639 Fioravante D, Byrne JH. 2011. Protein degradation and memory formation. Brain research bulletin $640 \quad 85: 14-20$.

641 Ghani M, Reitz C, St George-Hyslop P, Rogaeva E. 2018. Genetic Complexity of Early-Onset 642 Alzheimer's Disease. In: Neurodegenerative Diseases. Springer, 29-50.

643 Gong C-X, Liu F, Grundke-Iqbal I, Iqbal K. 2006. Dysregulation of protein 644 phosphorylation/dephosphorylation in Alzheimer's disease: a therapeutic target. BioMed $645 \quad$ Research International 2006. 
646 Gottschall PE, Howell MD. 2015. ADAMTS expression and function in central nervous system injury 647 and disorders. Matrix Biology 44:70-76.

648 Grbovic OM, Mathews PM, Jiang Y, Schmidt SD, Dinakar R, Summers-Terio NB, Ceresa BP, Nixon 649 RA, Cataldo AM. 2003. Rab5-stimulated up-regulation of the endocytic pathway increases 650 intracellular $\beta$-cleaved amyloid precursor protein carboxyl-terminal fragment levels and A $\beta$ $651 \quad$ production. Journal of Biological Chemistry 278:31261-31268.

652 Guglielmotto M, Monteleone D, Piras A, Valsecchi V, Tropiano M, Ariano S, Fornaro M, Vercelli A, 653 Puyal J, Arancio O. 2014. A $\beta 1-42$ monomers or oligomers have different effects on autophagy 654 and apoptosis. Autophagy 10:1827-1843.

655 Haddock G, Cross A, Plumb J, Surr J, Buttle D, Bunning RA, Woodroofe M. 2006. Expression of 656 ADAMTS-1,-4,-5 and TIMP-3 in normal and multiple sclerosis CNS white matter. Multiple Sclerosis Journal 12:386-396.

658

659

660

661

662

663

664

665

666

667 668

669

670

671

Hamann AR. 2018. Design and development of novel irreversible GSK-3 $\beta$ inhibitors to address Alzheimer's disease.

He P, Zhong Z, Lindholm K, Berning L, Lee W, Lemere C, Staufenbiel M, Li R, Shen Y. 2007. Deletion of tumor necrosis factor death receptor inhibits amyloid $\beta$ generation and prevents learning and memory deficits in Alzheimer's mice. J Cell Biol 178:829-841.

Herz J, Strickland DK. 2001. LRP: a multifunctional scavenger and signaling receptor. The Journal of clinical investigation 108:779-784.

Hisatsune C, Mikoshiba K. 2017. IP 3 receptor mutations and brain diseases in human and rodents. Journal of neurochemistry 141:790-807.

Hooper C, Killick R, Lovestone S. 2008. The GSK3 hypothesis of Alzheimer's disease. Journal of neurochemistry 104:1433-1439.

Hu J, Igarashi A, Kamata M, Nakagawa H. 2001. Angiotensin-converting enzyme degrades Alzheimer amyloid $\beta$-peptide $(\mathrm{A} \beta)$; retards $\mathrm{A} \beta$ aggregation, deposition, fibril formation; and inhibits cytotoxicity. Journal of Biological Chemistry 276:47863-47868. 
672 Huang Y-WA, Zhou B, Nabet AM, Wernig M, Südhof T. 2018. ApoE2, ApoE3 and ApoE4 Differentially 673 Impact Multiple Signaling Pathways Regulating Synaptogenesis. bioRxiv:460899.

674 Ivins KJ, Thornton PL, Rohn TT, Cotman CW. 1999. Neuronal apoptosis induced by $\beta$-amyloid is 675 mediated by caspase- 8 . Neurobiology of disease 6:440-449.

676 Jevnikar Z, Kos J. 2009. CTSB (cathepsin B). Atlas of Genetics and Cytogenetics in Oncology and 677 Haematology.

678 Jin S, Kedia N, Illes-Toth E, Haralampiev I, Prisner S, Herrmann A, Wanker EE, Bieschke J. 2016. 679 Amyloid- $\beta$ (1-42) aggregation initiates its cellular uptake and cytotoxicity. Journal of Biological $680 \quad$ Chemistry 291:19590-19606.

681 Jin M, Shepardson N, Yang T, Chen G, Walsh D, Selkoe DJ. 2011. Soluble amyloid $\beta$-protein dimers 682 isolated from Alzheimer cortex directly induce Tau hyperphosphorylation and neuritic

683

684

685

686

687

688

689

690

691

692

693

694

695

696 degeneration. Proceedings of the National Academy of Sciences 108:5819-5824.

Kabeya Y, Mizushima N, Yamamoto A, Oshitani-Okamoto S, Ohsumi Y, Yoshimori T. 2004. LC3, GABARAP and GATE16 localize to autophagosomal membrane depending on form-II formation. Journal of cell science 117:2805-2812.

Kim EK, Kwon J-E, Lee S-Y, Lee E-J, Moon S-J, Lee J, Kwok S-K, Park S-H, Cho M-L. 2018. IL-17mediated mitochondrial dysfunction impairs apoptosis in rheumatoid arthritis synovial fibroblasts through activation of autophagy. Cell death \& disease 8:e2565-e2565.

Kitamura Y, Shimohama S, Kamoshima W, Ota T, Matsuoka Y, Nomura Y, Smith MA, Perry G, Whitehouse PJ, Taniguchi T. 1998. Alteration of proteins regulating apoptosis, Bcl-2, Bcl-x, Bax, Bak, Bad, ICH-1 and CPP32, in Alzheimer's disease. Brain research 780:260-269.

Koffie RM, Meyer-Luehmann M, Hashimoto T, Adams KW, Mielke ML, Garcia-Alloza M, Micheva KD, Smith SJ, Kim ML, Lee VM. 2009. Oligomeric amyloid $\beta$ associates with postsynaptic densities and correlates with excitatory synapse loss near senile plaques. Proceedings of the National Academy of Sciences 106:4012-4017. 
697 Koo SJ, Markovic S, Puchkov D, Mahrenholz CC, Beceren-Braun F, Maritzen T, Dernedde J, Volkmer

698 R, Oschkinat H, Haucke V. 2011. SNARE motif-mediated sorting of synaptobrevin by the 699 endocytic adaptors clathrin assembly lymphoid myeloid leukemia (CALM) and AP180 at $700 \quad$ synapses. Proceedings of the National Academy of Sciences 108:13540-13545.

701 Lacor PN, Buniel MC, Chang L, Fernandez SJ, Gong Y, Viola KL, Lambert MP, Velasco PT, Bigio EH, 702 Finch CE. 2004. Synaptic targeting by Alzheimer's-related amyloid $\beta$ oligomers. Journal of $703 \quad$ Neuroscience 24:10191-10200.

704 Lagercrantz J, Carson E, Phelan C, Grimmond S, Rosén A, Daré E, Nordenskjöld M, Hayward NK, 705 Larsson C, Weber G. 1995. Genomic organization and complete cDNA sequence of the human 706 phosphoinositide-specific phospholipase C $\beta 3$ gene (PLCB3). Genomics 26:467-472.

707 Lambert J-C, Ibrahim-Verbaas CA, Harold D, Naj AC, Sims R, Bellenguez C, Jun G, DeStefano AL, Bis 708 709 JC, Beecham GW. 2013. Meta-analysis of 74,046 individuals identifies 11 new susceptibility loci for Alzheimer's disease. Nature genetics 45:1452.

710

711

712

713

714

715

716

717

718

719

720

721

722

Maia MA, Sousa E. 2019. BACE-1 and $\gamma$-Secretase as Therapeutic Targets for Alzheimer's Disease. Pharmaceuticals 12:41.

Manap A, Syamima A, Tan ACW, Leong WH, Chia AYY, Vijayabalan S, Arya A, Wong EH, Rizwan F, Bindal U. 2019. Synergistic Effects of Curcumin and Piperine as Potent Acetylcholine and Amyloidogenic Inhibitors With Significant Neuroprotective Activity in SH-SY5Y Cells via Computational Molecular Modeling and in vitro Assay. Frontiers in aging neuroscience 11:206.

McAlpine FE, Tansey MG. 2008. Neuroinflammation and tumor necrosis factor signaling in the pathophysiology of Alzheimer's disease. Journal of inflammation research 1:29.

Metzstein MM, Stanfield GM, Horvitz HR. 1998. Genetics of programmed cell death in C. elegans: past, present and future. Trends in genetics 14:410-416.

Miguel RF, Pollak A, Lubec G. 2005. Metalloproteinase ADAMTS-1 but not ADAMTS-5 is manifold overexpressed in neurodegenerative disorders as Down syndrome, Alzheimer's and Pick's disease. Molecular brain research 133:1-5. 
723 Miners JS, Barua N, Kehoe PG, Gill S, Love S. 2011. A $\beta$-degrading enzymes: potential for treatment of 724 Alzheimer disease. Journal of Neuropathology \& Experimental Neurology 70:944-959.

725 Miners S, van Helmond Z, Barker R, Passmore PA, Johnston JA, Todd S, McGuinness BM, Panza F, 726 Seripa D, Solfrizzi V. 2012. Genetic variation in MME in relation to neprilysin protein and 727 enzyme activity, A $\beta$ levels, and Alzheimer's disease risk. International journal of molecular $728 \quad$ epidemiology and genetics 3:30.

729 Molnár Z, Soós K, Lengyel I, Penke B, Szegedi V, Budai D. 2004. Enhancement of NMDA responses by $730 \quad \beta$-amyloid peptides in the hippocampus in vivo. Neuroreport 15:1649-1652.

731 Moon SW, Park H, Kam T-I, Kim Y, Jung Y-K. 2017. REGULATION OF A $\beta$-OR ROS-MEDIATED

732 NEURITE DEGENERATION BY AK5. Alzheimer's \& Dementia: The Journal of the

733 Alzheimer's Association 13:P1299.

734

735

736

737

738

739

740

741

742

743

744

745

746

747 748

Moreau K, Fleming A, Imarisio S, Ramirez AL, Mercer JL, Jimenez-Sanchez M, Bento CF, Puri C, Zavodszky E, Siddiqi F. 2015. PICALM modulates autophagy activity and tau accumulation (vol 5, 4998, 2014). NATURE COMMUNICATIONS 6.

Mueller-Steiner S, Zhou Y, Arai H, Roberson ED, Sun B, Chen J, Wang X, Yu G, Esposito L, Mucke L. 2006. Antiamyloidogenic and neuroprotective functions of cathepsin B: implications for Alzheimer's disease. Neuron 51:703-714.

Muzio M, Chinnaiyan AM, Kischkel FC, O’Rourke K, Shevchenko A, Ni J, Scaffidi C, Bretz JD, Zhang M, Gentz R. 1996. FLICE, a novel FADD-homologous ICE/CED-3-like protease, is recruited to the CD95 (Fas/APO-1) death-inducing signaling complex. Cell 85:817-827.

Myers A, McGonigle P. 2019. Overview of Transgenic Mouse Models for Alzheimer's Disease. Current Protocols in Neuroscience 89:e81.

Nakatogawa H. 2013. Two ubiquitin-like conjugation systems that mediate membrane formation during autophagy. Essays in Biochemistry 55:39-50.

Nakhaei-Rad S, Haghighi F, Nouri P, Rezaei Adariani S, Lissy J, Kazemein Jasemi NS, Dvorsky R, Ahmadian MR. 2018. Structural fingerprints, interactions, and signaling networks of RAS family 
749 750

\section{1}

752

753

754

755

756

757

758

759

760

761

762

763

764

765

766

767

768

769

770

771

772

773

774

proteins beyond RAS isoforms. Critical reviews in biochemistry and molecular biology 53:130156.

Nixon RA. 2017. Amyloid precursor protein and endosomal-lysosomal dysfunction in Alzheimer's disease: inseparable partners in a multifactorial disease. The FASEB Journal 31:2729-2743.

Ozcelik T, Lafreniere R, Archer 3rd B, Johnston P, Willard H, Francke U, Südhof T. 1990. Synaptophysin: structure of the human gene and assignment to the $\mathrm{X}$ chromosome in man and mouse. American journal of human genetics 47:551.

Panza F, Lozupone M, Bellomo A, Imbimbo BP. 2019. Do Anti-Amyloid- $\beta$ Drugs affect Neuropsychiatric Status in Alzheimer's Disease Patients? Ageing research reviews:100948.

Pehlivan S, Fedakar R, Eren B, Akyol S, Eren F, Inanir NT, Gurses MS, Ural MN, Tagil SM, Demircan K. 2016. ADAMTS4, 5, 9, and 15 expressions in the autopsied brain of patients with Alzheimer's disease: a preliminary immunohistochemistry study. Klinik Psikofarmakoloji Bülteni-Bulletin of Clinical Psychopharmacology 26:7-14.

Pekny M, Nilsson M. 2005. Astrocyte activation and reactive gliosis. Glia 50:427-434.

Pink AE, Simpson MA, Desai N, Trembath RC, Barker JN. 2013. $\gamma$-Secretase mutations in hidradenitis suppurativa: new insights into disease pathogenesis. Journal of Investigative Dermatology $133: 601-607$.

Porter S, Clark IM, Kevorkian L, Edwards DR. 2005. The ADAMTS metalloproteinases. Biochemical Journal 386:15-27.

Ramos-Miguel A, García-Sevilla JA, Barr AM, Bayer TA, Falkai P, Leurgans SE, Schneider JA, Bennett DA, Honer WG, García-Fuster MJ. 2017. Decreased cortical FADD protein is associated with clinical dementia and cognitive decline in an elderly community sample. Molecular neurodegeneration 12:26.

Reddy PH, Mani G, Park BS, Jacques J, Murdoch G, Whetsell Jr W, Kaye J, Manczak M. 2005. Differential loss of synaptic proteins in Alzheimer's disease: implications for synaptic dysfunction. Journal of Alzheimer's Disease 7:103-117.

Peer) reviewing PDF | (2020:02:45631:2:1:NEW 24 Aug 2020) 
775 Rehker J, Rodhe J, Nesbitt RR, Boyle EA, Martin BK, Lord J, Karaca I, Naj A, Jessen F, Helisalmi S. 776 2017. Caspase-8, association with Alzheimer's Disease and functional analysis of rare variants. $777 \quad$ PloS one 12:e0185777.

778 Ribarič S, Ribarič IM. 2019. Autophagy and Cell Death in Alzheimer's, Parkinson's and Prion Diseases. 779 In: Programmed Cell Death. IntechOpen,.

780 Russell CL, Semerdjieva S, Empson RM, Austen BM, Beesley PW, Alifragis P. 2012. Amyloid- $\beta$ acts as 781 a regulator of neurotransmitter release disrupting the interaction between synaptophysin and 782 VAMP2. PloS one 7:e43201.

783

784

785

786

787

788

789

790

791

792

793

794

795

796

797

798

799

Safieh M, Korczyn AD, Michaelson DM. 2019. ApoE4: an emerging therapeutic target for Alzheimer's disease. BMC medicine 17:64.

Sajan FD, Martiniuk F, Marcus DL, Frey WH, Hite R, Bordayo EZ, Freedman ML. 2007. Apoptotic gene expression in Alzheimer's disease hippocampal tissue. American Journal of Alzheimer's Disease \& Other Dementias ${ }^{\circledR} 22: 319-328$.

Schmittgen TD, Livak KJ. 2008. Analyzing real-time PCR data by the comparative C T method. Nature protocols 3:1101.

Smith DL, Pozueta J, Gong B, Arancio O, Shelanski M. 2009. Reversal of long-term dendritic spine alterations in Alzheimer disease models. Proceedings of the National Academy of Sciences 106:16877-16882.

Sproul AA, Jacob S, Pre D, Kim SH, Nestor MW, Navarro-Sobrino M, Santa-Maria I, Zimmer M, Aubry S, Steele JW. 2014. Characterization and molecular profiling of PSEN1 familial Alzheimer's disease iPSC-derived neural progenitors. PloS one 9:e84547.

Stocker H, Möllers T, Perna L, Brenner H. 2018. The genetic risk of Alzheimer's disease beyond APOE ع4: systematic review of Alzheimer's genetic risk scores. Translational psychiatry 8:1-9.

Storck SE, Pietrzik CU. 2017. Endothelial LRP1-A Potential Target for the Treatment of Alzheimer's Disease. Pharmaceutical research 34:2637-2651. 
800 Sulatskaya A, Rodina N, Sulatsky M, Povarova O, Antifeeva I, Kuznetsova I, Turoverov K. 2018.

801 Investigation of $\alpha$-synuclein amyloid fibrils using the fluorescent probe thioflavin T.

$802 \quad$ International journal of molecular sciences 19:2486.

803 Sun X, Meng X, Zhang J, Li Y, Wang L, Qin X, Sui N, Zhang Y. 2012. GABA attenuates amyloid 804 toxicity by downregulating its endocytosis and improves cognitive impairment. Journal of 805 Alzheimer's Disease 31:635-649.

806 Tan JZA, Gleeson PA. 2019. The role of membrane trafficking in the processing of amyloid precursor 807 protein and production of amyloid peptides in Alzheimer's disease. Biochimica et Biophysica $808 \quad$ Acta (BBA)-Biomembranes.

809 Thornberry NA, Lazebnik Y. 1998. Caspases: enemies within. Science 281:1312-1316.

810 Tycko R. 2018. Fibril Formation by Amyloid-beta and by Low-complexity Sequences: Insights from $811 \quad$ Solid State NMR. Biophysical Journal 114:185a.

812 Ulrich D. 2015. Amyloid- $\beta$ impairs synaptic inhibition via GABAA receptor endocytosis. Journal of $813 \quad$ Neuroscience 35:9205-9210.

814 Van Leeuwen F, Hol E, Fischer D. 2006. Frameshift proteins in Alzheimer's disease and in other 815 conformational disorders: time for the ubiquitin-proteasome system. Journal of Alzheimer's $816 \quad$ Disease 9:319-325.

817 Vepsäläinen S, Parkinson M, Helisalmi S, Mannermaa A, Soininen H, Tanzi RE, Bertram L, Hiltunen M. 818 2007. Insulin-degrading enzyme is genetically associated with Alzheimer's disease in the Finnish 819 population. Journal of medical genetics 44:606-608.

820 Vitolo OV, Sant'Angelo A, Costanzo V, Battaglia F, Arancio O, Shelanski M. 2002. Amyloid $\beta$-peptide 821 inhibition of the PKA/CREB pathway and long-term potentiation: reversibility by drugs that 822 enhance cAMP signaling. Proceedings of the National Academy of Sciences 99:13217-13221.

823 Wang Y, Jia J. 2009. Association between promoter polymorphisms in anterior pharynx-defective-1a and 824 sporadic Alzheimer's disease in the North Chinese Han population. Neuroscience letters $825 \quad 455: 101-104$. 
826 Wang Z, McCloskey A, Cheng S, Wu M, Xue C, Yu Z, Fu J, Liu Y, Luo Z-Q, Liu X. 2018a. Regulation 827 of the small GTPase Rab1 function by a bacterial glucosyltransferase. Cell discovery 4:53.

828 Wang C, Najm R, Xu Q, Jeong D, Walker D, Balestra ME, Yoon SY, Yuan H, Li G, Miller ZA. 2018 b. 829 Gain of toxic apolipoprotein E4 effects in human iPSC-derived neurons is ameliorated by a small830 molecule structure corrector. Nature medicine 24:647.

831 Watson D, Castaño E, Kokjohn TA, Kuo Y-M, Lyubchenko Y, Pinsky D, Connolly ES, Esh C, Luehrs 832 DC, Stine WB. 2005. Physicochemical characteristics of soluble oligomeric A $\beta$ and their 833 pathologic role in Alzheimer's disease. Neurological research 27:869-881.

834 Wen Y, Yu WH, Maloney B, Bailey J, Ma J, Marié I, Maurin T, Wang L, Figueroa H, Herman M. 2008.

835 Transcriptional regulation of $\beta$-secretase by $\mathrm{p} 25 / \mathrm{cdk} 5$ leads to enhanced amyloidogenic $836 \quad$ processing. Neuron 57:680-690.

837 Wiedenmann B, Franke WW. 1985. Identification and localization of synaptophysin, an integral 838 membrane glycoprotein of Mr 38,000 characteristic of presynaptic vesicles. Cell 41:1017-1028.

839

840

841 842

843

844

845

846

847

848

849 850
Xu W, Tan L, Yu J-T. 2015. The role of PICALM in Alzheimer's disease. Molecular neurobiology 52:399-413.

Xue C, Lin TY, Chang D, Guo Z. 2017. Thioflavin T as an amyloid dye: fibril quantification, optimal concentration and effect on aggregation. Royal Society open science 4:160696.

Yang AJ, Frendo-Cumbo S, MacPherson RE. 2019. Resveratrol and Metformin Recover Prefrontal Cortex AMPK Activation in Diet-Induced Obese Mice but Reduce BDNF and Synaptophysin Protein Content. Journal of Alzheimer's Disease:1-12.

Yu WH, Cuervo AM, Kumar A, Peterhoff CM, Schmidt SD, Lee J-H, Mohan PS, Mercken M, Farmery MR, Tjernberg LO. 2005. Macroautophagy — a novel $\beta$-amyloid peptide-generating pathway activated in Alzheimer's disease. J Cell Biol 171:87-98.

Zeidán-Chuliá F, de Oliveira B-H, Salmina AB, Casanova MF, Gelain DP, Noda M, Verkhratsky A, Moreira JC. 2014. Altered expression of Alzheimer's disease-related genes in the cerebellum of

Peer) reviewing PDF | (2020:02:45631:2:1:NEW 24 Aug 2020) 
851 autistic patients: a model for disrupted brain connectome and therapy. Cell death \& disease

$852 \quad 5: e 1250$.

853 Zhao P, Qian X, Nie Y, Sun N, Wang Z, Wu J, Wei C, Ma R, Wang Z, Chai G. 2019. Neuropeptide S

854 ameliorates cognitive impairment of APP/PS1 transgenic mice by promoting synaptic plasticity

$855 \quad$ and reducing A $\beta$ deposition. Frontiers in behavioral neuroscience 13:138.

856 Zhao Z, Sagare AP, Ma Q, Halliday MR, Kong P, Kisler K, Winkler EA, Ramanathan A, Kanekiyo T, Bu

857 G. 2015. Central role for PICALM in amyloid- $\beta$ blood-brain barrier transcytosis and clearance.

$858 \quad$ Nature neuroscience 18:978.

859 Zhou G, Soufan O, Ewald J, Hancock RE, Basu N, Xia J. 2019. NetworkAnalyst 3.0: a visual analytics

860 platform for comprehensive gene expression profiling and meta-analysis. Nucleic acids research.

861 


\section{Table 1 (on next page)}

Number of significant differentially expressed genes compared between treatment (curcumin and piperine singularly; combined curcumin and piperine) and control groups $(A \beta)$. 
1 Table 1: Number of significant differentially expressed genes compared between treatment 2 (curcumin and piperine singularly; combined curcumin and piperine) and control groups (A $\beta$ ).

\begin{tabular}{cccc}
\hline \multirow{2}{*}{ Expression of genes } & \multicolumn{3}{c}{ Total number of up and down regulated genes } \\
\cline { 2 - 4 } & {$[\mathrm{CuR}+\mathrm{A} \beta]$ vs. $\mathrm{A} \beta$} & {$[$ Pip $+\mathrm{A} \beta]$ vs. $\mathrm{A} \beta$} & {$[\mathrm{CP}+\mathrm{A} \beta]$ vs. $\mathrm{A} \beta$} \\
\hline Up-regulated & 1723 & 2028 & 1210 \\
\hline Down-regulated & 1481 & 1635 & 1904 \\
\hline Total genes & 3204 & 3663 & 3114 \\
\hline
\end{tabular}

3

4 


\section{Table 2 (on next page)}

Top 10 most significantly up-regulated and down-regulated genes between AB-SH-SY5Y cells treated with curcumin and untreated cells. 
1 Table 2. Top-10 up-regulated and top 10 down-regulated most significant differentially expressed genes regulated by [CuR $+\mathrm{A} \beta]$ with 2 A $\beta$ alone

\begin{tabular}{|c|c|c|c|c|c|c|c|}
\hline No. & Transcript ID & $\begin{array}{l}\text { Top } 10 \text { up- } \\
\text { regulated genes }\end{array}$ & $\begin{array}{l}\text { Top } 10 \text { down- } \\
\text { regulated genes }\end{array}$ & P-value & $\begin{array}{l}\text { Fold- } \\
\text { change }\end{array}$ & $\begin{array}{l}\text { Entrez } \\
\text { ID }\end{array}$ & Protein Description \\
\hline 2. & TC1200006787.hg.1 & GABARAPL1 & & $1.31 \mathrm{E}-09$ & 5.29 & 23710 & $\begin{array}{c}\text { GABA(A) receptor-associated protein } \\
\text { like } 1\end{array}$ \\
\hline 3. & TC0700012180.hg.1 & SYPL1 & & $4.56 \mathrm{E}-09$ & 2.04 & 6856 & synaptophysin-like 1 \\
\hline 4. & TC1100011838.hg.1 & PICALM & & $8.10 \mathrm{E}-09$ & 5.04 & 8301 & $\begin{array}{l}\text { phosphatidylinositol binding clathrin } \\
\text { assembly protein }\end{array}$ \\
\hline 7 & TC0300012145.hg.1 & FSTL1 & - & $3.38 \mathrm{E}-08$ & 6.62 & 11167 & follistatin like 1; microRNA 198 \\
\hline 8 & TC0200016424.hg.1 & $L B H$ & - & $3.77 \mathrm{E}-08$ & 16.14 & 81606 & limb bud and heart development \\
\hline 9 & TC0400010602.hg.1 & GABRA4 & - & $3.89 \mathrm{E}-08$ & 12.58 & 2557 & $\begin{array}{l}\text { gamma-aminobutyric acid (GABA) A } \\
\text { receptor, alpha } 4\end{array}$ \\
\hline 10 & TC0600008780.hg.1 & CASP8AP2 & - & 3.93E-08 & 3.29 & 9994 & caspase 8 associated protein 2 \\
\hline 15 & TC1000006891.hg.1 & - & $V I M$ & $4.12 \mathrm{E}-07$ & -3.81 & 7431 & vimentin \\
\hline 16 & TC1200009734.hg.1 & - & VAMP1 & $4.63 \mathrm{E}-07$ & -4.25 & 6843 & vesicle associated membrane protein 1 \\
\hline 17 & TC2000009915.hg.1 & - & $R A B 5 B$ & $1.44 \mathrm{E}-06$ & -2.23 & 55969 & Rab5-interacting protein family \\
\hline 18 & TC1100012633.hg.1 & - & $S C N 3 B$ & $1.50 \mathrm{E}-06$ & -8.22 & 55800 & Immunoglobulin V-set domain \\
\hline 19 & TC1200008176.hg.1 & - & LGR5 & $1.61 \mathrm{E}-06$ & -3.14 & 8549 & G protein-coupled receptor \\
\hline 20 & TC1000008556.hg.1 & - & $L C O R$ & $1.79 \mathrm{E}-06$ & -4.49 & 84458 & $\begin{array}{l}\text { ligand dependent nuclear receptor } \\
\text { corepressor like }\end{array}$ \\
\hline
\end{tabular}

3 (CuR: Curcumin; Pip: Piperine and CP: Combined curcumin and piperine) 


\section{Table 3(on next page)}

Top 10 most significant up-regulated and down-regulated genes between A $3-\mathrm{SH}-\mathrm{SY} 5 \mathrm{Y}$ cells treated with piperine and untreated cells. 
1 Table 3. Top 10 most significant up-regulated and down-regulated genes between A $\beta$-SH-SY5Y cells treated with piperine and untreated 2 cells.

\begin{tabular}{|c|c|c|c|c|c|c|c|}
\hline No. & Transcript ID & $\begin{array}{l}\text { Top } 10 \text { up- } \\
\text { regulated genes }\end{array}$ & $\begin{array}{l}\text { Top } 10 \text { down- } \\
\text { regulated genes }\end{array}$ & P-value & $\begin{array}{l}\text { Fold- } \\
\text { change }\end{array}$ & Entrez ID & Protein Description \\
\hline 1 & TC1200006787.hg.1 & GABARAPL1 & - & $2.87 \mathrm{E}-09$ & 17.61 & 23710 & GABA(A) receptor-associated protein like 1 \\
\hline 2 & TC0200015887.hg.1 & CUL3 & - & $4.02 \mathrm{E}-09$ & 23.68 & 8452 & Cullin, N-terminal; Cullin protein \\
\hline 3 & TC0600008780.hg.1 & CASP8AP2 & - & $9.73 \mathrm{E}-09$ & 13.46 & 9994 & Caspase 8 associated protein 2 \\
\hline 4 & TC1500010244.hg.1 & $A P 3 B 2$ & - & $1.13 \mathrm{E}-08$ & 25.45 & 8120 & Adaptor-related protein complex 3 \\
\hline 5 & TC0200010607.hg.1 & CREBI & - & $2.00 \mathrm{E}-08$ & 31.86 & 1385 & cAMP responsive element binding protein 1 \\
\hline 6 & TC0400012551.hg.1 & DCTD & - & $2.85 \mathrm{E}-08$ & 6.00 & 1635 & Cytidine and deoxycytidylate deaminases \\
\hline 7 & TC0X00010851.hg.1 & GPC3 & - & $3.39 \mathrm{E}-08$ & 7.16 & 2719 & glypican 3 \\
\hline 8 & TC0800009619.hg.1 & $C T S B$ & - & $4.36 \mathrm{E}-08$ & 17.33 & 1508 & cathepsin B \\
\hline 9 & TC0300012145.hg.1 & FSTL1 & - & $5.71 \mathrm{E}-08$ & 15.96 & 11167 & Osteonectin EGF domain \\
\hline 10 & TC0400010602.hg.1 & GABRA4 & - & $6.04 \mathrm{E}-08$ & 4.22 & 2557 & $\begin{array}{l}\text { gamma-aminobutyric acid (GABA) A } \\
\text { receptor, alpha } 4\end{array}$ \\
\hline 11 & TC1000008767.hg.1 & - & $I N A$ & $2.23 \mathrm{E}-08$ & -10.07 & 9118 & $\begin{array}{l}\text { internexin neuronal intermediate filament } \\
\text { protein, alpha }\end{array}$ \\
\hline 12 & TC2000009915.hg.1 & - & $R A B 5 B$ & $3.45 \mathrm{E}-08$ & -15.27 & 55969 & Rab5-interacting protein family \\
\hline 13 & TC0900009145.hg.1 & - & OLFMI & $3.72 \mathrm{E}-08$ & -7.57 & 10439 & olfactomedin 1 \\
\hline 14 & TC1400010728.hg.1 & - & HEATR5A & $8.10 \mathrm{E}-08$ & -7.57 & 25938 & HEAT repeat containing $5 \mathrm{~A}$ \\
\hline 15 & TC1200009734.hg.1 & - & $V A M P 1$ & $1.32 \mathrm{E}-07$ & -4.29 & 6843 & vesicle associated membrane protein 1 \\
\hline 16 & TC1400007628.hg.1 & - & PSEN1 & $1.34 \mathrm{E}-07$ & -15.29 & 5663 & presenilin 1 \\
\hline 17. & TC0100008797.hg.1 & & $A K 5$ & $1.59 \mathrm{E}-07$ & -15.36 & 26289 & adenylate kinase 5 \\
\hline 18 & TC1500009082.hg.1 & - & $B M F$ & $1.65 \mathrm{E}-07$ & -5.07 & 90427 & Bcl2 modifying factor \\
\hline 19 & TC1300008125.hg.1 & - & LAMP1 & $1.80 \mathrm{E}-07$ & -5.24 & 7431 & lysosomal-associated membrane protein 1 \\
\hline 20 & TC0800007688.hg.1 & - & $L Y N$ & $2.14 \mathrm{E}-07$ & -17.16 & 4067 & LYN proto-oncogene \\
\hline
\end{tabular}

3 


\section{Table 4 (on next page)}

Top 10 most significant up-regulated and down-regulated genes between A $3-\mathrm{SH}-\mathrm{SY} 5 \mathrm{Y}$ cells treated with curcumin-piperine in combination and untreated cells. 
1 Table 4. Top 10 most significant up-regulated and down-regulated genes between A $\beta$-SH-SY5Y cells treated with curcumin-piperine in 2 combination and untreated cells.

\begin{tabular}{|c|c|c|c|c|c|c|c|}
\hline No. & Transcript ID & $\begin{array}{l}\text { Top } 10 \text { up- } \\
\text { regulated } \\
\text { genes }\end{array}$ & $\begin{array}{l}\text { Top } 10 \text { down- } \\
\text { regulated genes }\end{array}$ & P-value & $\begin{array}{l}\text { Fold- } \\
\text { change }\end{array}$ & $\begin{array}{l}\text { Entrez } \\
\text { ID }\end{array}$ & Protein Description \\
\hline 1 & TC1200006787.hg.1 & GABARAPL1 & & $1.06 \mathrm{E}-07$ & 18.72 & 23710 & GABA(A) receptor-associated protein like 1 \\
\hline 2 & TC1100008262.hg.1 & $F A D D$ & - & $1.11 \mathrm{E}-07$ & 22.91 & 8772 & Fas (TNFRSF6)-associated via death domain \\
\hline 3 & TC1200007861.hg.1 & $L R P 1$ & - & $1.64 \mathrm{E}-07$ & 5.77 & 4035 & LDL receptor related protein 1 \\
\hline 4 & TC2000007900.hg.1 & $V A P B$ & - & $1.97 \mathrm{E}-07$ & 4.61 & 9217 & $\begin{array}{l}\text { VAMP (vesicle-associated membrane protein)- } \\
\text { associated protein B and C }\end{array}$ \\
\hline 5 & TC1500010244.hg.1 & $A P 3 B 2$ & - & $2.21 \mathrm{E}-07$ & 4.49 & 8120 & Adaptor-related protein complex 3 \\
\hline 6 & TC0800009619.hg.1 & $C T S B$ & - & $2.22 \mathrm{E}-07$ & 3.65 & 1508 & cathepsin B \\
\hline 7 & TC0200015887.hg.1 & CUL3 & & 2.72E-07 & 3.53 & 8452 & Cullin, N-terminal; Cullin protein \\
\hline 8 & TC2100007822.hg.1 & ADAMTS5 & - & $1.97 \mathrm{E}-07$ & 5.08 & 11096 & $\begin{array}{l}\text { ADAM metallopeptidase with thrombospondin } \\
\text { type } 1 \text { motif } 5\end{array}$ \\
\hline 9 & TC1500010350.hg.1 & NTRK3 & - & $3.43 \mathrm{E}-07$ & 5.73 & 4916 & neurotrophic tyrosine kinase, receptor, type 3 \\
\hline 10 & TC1800006513.hg.1 & TGIF1 & - & $3.88 \mathrm{E}-07$ & 16.28 & 7050 & TGFB-induced factor homeobox 1 \\
\hline 11 & TC2000006674.hg.1 & - & PLCB4 & $2.89 \mathrm{E}-07$ & -3.40 & 5332 & phospholipase $\mathrm{C}$, beta 4 \\
\hline 12 & TC1200008176.hg.1 & - & $L G R 5$ & $3.76 \mathrm{E}-07$ & -5.16 & 8549 & $\begin{array}{l}\text { leucine-rich repeat containing G protein- } \\
\text { coupled receptor } 5\end{array}$ \\
\hline 13 & TC0600010960.hg.1 & - & $T P M T$ & 3.99E-07 & -13.43 & 7172 & thiopurine S-methyltransferase \\
\hline 14 & TC1000006891.hg.1 & - & $V I M$ & 4.77E-07 & -5.42 & 7431 & vimentin \\
\hline 15 & TC0900009145.hg.1 & & $O L F M 1$ & $5.50 \mathrm{E}-07$ & -2.37 & 10439 & olfactomedin 1 \\
\hline 16 & TC0M00006440.hg.1 & - & ND3 & $5.68 \mathrm{E}-07$ & -2.54 & NA & NADH dehydrogenase, subunit 3 (complex I) \\
\hline 17 & TC2000009915.hg.1 & - & $R A B 5 B$ & $7.15 \mathrm{E}-07$ & -10.21 & 55969 & Rab5-interacting protein family \\
\hline 18 & TC0100008797.hg.1 & & $A K 5$ & $8.78 \mathrm{E}-07$ & -14.69 & 26289 & adenylate kinase 5 \\
\hline 19 & TC0800007688.hg.1 & - & $L Y N$ & $1.03 \mathrm{E}-06$ & -6.87 & 4067 & LYN proto-oncogene \\
\hline 20 & TC1000008767.hg.1 & - & INA & $1.17 \mathrm{E}-06$ & -3.88 & 9118 & $\begin{array}{l}\text { internexin neuronal intermediate filament } \\
\text { protein, alpha }\end{array}$ \\
\hline
\end{tabular}




\section{Table 5 (on next page)}

Top 20 most significant differentially expressed genes in all three groups (CuR $+A \beta$ vs. $A \beta ;$ Pip $+A \beta$ vs. $A \beta \& C P+A \beta$ vs. $A \beta$. 
Table 5. Top 20 most significant differentially expressed genes in all three groups $(\mathrm{CuR}+\mathrm{A} \beta$ vs. $\mathrm{A} \beta$; Pip $+\mathrm{A} \beta$ vs. $\mathrm{A} \beta$ \& $\mathrm{CP}+\mathrm{A} \beta$ vs. $2 \mathrm{~A} \beta)$

\begin{tabular}{|c|c|c|c|}
\hline Transcript ID & Gene symbol & Description & Entrez ID \\
\hline TC0100008797.hg.1 & $A K 5$ & adenylate kinase 5 & 26289 \\
\hline TC0100015895.hg.1 & $R A B 13$ & RAB13, member RAS oncogene family & 5872 \\
\hline TC0200011975.hg.1 & TP53I3 & tumor protein p53 inducible protein 3 & 9540 \\
\hline TC1000012169.hg.1 & $A D A M 12$ & ADAM metallopeptidase domain 12 & 8038 \\
\hline TC1100008262.hg.1 & $F A D D$ & Fas (TNFRSF6)-associated via death domain & 8772 \\
\hline TC1200006787.hg.1 & GABARAPL1 & GABA(A) receptor-associated protein like 1 & 23710 \\
\hline TC1600009202.hg.1 & $C R E B B P$ & CREB binding protein & 1387 \\
\hline TSUnmapped00000228.hg.1 & NDUFA10 & $\begin{array}{l}\text { NADH dehydrogenase (ubiquinone) } 1 \text { alpha subcomplex, } \\
\qquad 10,42 \mathrm{kDa}\end{array}$ & 4705 \\
\hline TC0100014349.hg.1 & $J U N$ & jun proto-oncogene & 3725 \\
\hline TC0200007096.hg.1 & FOSL2 & FOS-like antigen 2 & 2355 \\
\hline TC0100007789.hg.1 & $A G O 3$ & argonaute RISC catalytic component 3 & 192669 \\
\hline TC0100008243.hg.1 & ELAVL4 & ELAV like neuron-specific RNA binding protein 4 & 1996 \\
\hline TC0100008517.hg.1 & NFIA & nuclear factor $\mathrm{I} / \mathrm{A}$ & 4774 \\
\hline TC0100008554.hg.1 & USP1 & ubiquitin specific peptidase 1 & 7398 \\
\hline TC0100008664.hg.1 & GADD45A & growth arrest and DNA-damage-inducible, alpha & 1647 \\
\hline TC0100008692.hg.1 & SRSF11 & serine/arginine-rich splicing factor 11 & 9295 \\
\hline TC0100008845.hg.1 & $A D G R L 2$ & adhesion $\mathrm{G}$ protein-coupled receptor L2 & 23266 \\
\hline TC0100008912.hg.1 & CYR61 & cysteine-rich, angiogenic inducer, 61 & 3491 \\
\hline TC0100008938.hg.1 & LMO4 & LIM domain only 4 & 8543 \\
\hline TC0100009020.hg.1 & $C D C 7$ & cell division cycle 7 & 8317 \\
\hline
\end{tabular}


Table 6(on next page)

Shows top 20 most significant pathway $(p<0.05)$ appeared in 1045 genes that are involved or potentially involved in Alzheimer Disease. 
1 Table 6. Shows top 20 most significant pathway $(\mathrm{p}<0.05)$ appeared in 1045 genes that are

2 involved or potentially involved in Alzheimer Disease.

\begin{tabular}{|c|c|c|c|c|c|}
\hline Pathway & Total & Expected & Hits & P.Value & FDR \\
\hline Alzheimer's disease & 171 & 12.7 & 74 & $3.22 \mathrm{E}-41$ & $1.02 \mathrm{E}-38$ \\
\hline Long-term potentiation & 67 & 4.99 & 74 & $2.18 \mathrm{E}-36$ & $3.46 \mathrm{E}-34$ \\
\hline TGF-beta signaling pathway & 92 & 6.85 & 124 & $1.47 \mathrm{E}-33$ & $1.56 \mathrm{E}-31$ \\
\hline Dopaminergic synapse & 131 & 9.75 & 52 & $3.58 \mathrm{E}-30$ & 2.84E-28 \\
\hline Choline metabolism in cancer & 99 & 7.37 & 69 & $2.96 \mathrm{E}-29$ & $1.88 \mathrm{E}-27$ \\
\hline Basal transcription factors & 45 & 3.35 & 56 & $3.62 \mathrm{E}-28$ & $1.92 \mathrm{E}-26$ \\
\hline Basal cell carcinoma & 63 & 4.69 & 69 & $1.11 \mathrm{E}-26$ & $5.02 \mathrm{E}-25$ \\
\hline Cytokine-cytokine receptor interaction & 294 & 21.9 & 50 & $4.42 \mathrm{E}-25$ & $1.76 \mathrm{E}-23$ \\
\hline cAMP signaling pathway & 212 & 15.8 & 43 & $1.30 \mathrm{E}-24$ & 4.61E-23 \\
\hline Apoptosis - multiple species & 33 & 2.46 & 62 & $1.79 \mathrm{E}-23$ & $5.69 \mathrm{E}-22$ \\
\hline Insulin signaling pathway & 137 & 10.2 & 54 & $2.21 \mathrm{E}-23$ & $6.39 \mathrm{E}-22$ \\
\hline Ras signaling pathway & 232 & 17.3 & 58 & $2.86 \mathrm{E}-22$ & 7.59E-21 \\
\hline Ubiquitin mediated proteolysis & 137 & 10.2 & 42 & $2.97 \mathrm{E}-21$ & 7.27E-20 \\
\hline Adipocytokine signaling pathway & 69 & 5.14 & 41 & $1.72 \mathrm{E}-20$ & $3.90 \mathrm{E}-19$ \\
\hline B cell receptor signaling pathway & 71 & 5.29 & 33 & $1.80 \mathrm{E}-19$ & 3.82E-18 \\
\hline Autophagy & 128 & 9.53 & 51 & $3.07 \mathrm{E}-19$ & $6.11 \mathrm{E}-18$ \\
\hline p53 signaling pathway & 72 & 5.36 & 34 & $4.05 \mathrm{E}-19$ & $7.58 \mathrm{E}-18$ \\
\hline NF-kappa B signaling pathway & 100 & 7.44 & 44 & $5.76 \mathrm{E}-19$ & $1.02 \mathrm{E}-17$ \\
\hline FoxO signaling pathway & 132 & 9.83 & 52 & $1.20 \mathrm{E}-18$ & $2.01 \mathrm{E}-17$ \\
\hline $\begin{array}{l}\text { AGE-RAGE signaling pathway in } \\
\text { diabetic complications }\end{array}$ & 100 & 7.44 & 45 & $3.35 \mathrm{E}-18$ & 5.32E-17 \\
\hline
\end{tabular}




\section{Table 7 (on next page)}

25 differentially expressed genes involved in AD pathway. 
1 Table 7.25 differentially expressed genes involved in AD pathway.

\begin{tabular}{|c|c|c|c|c|c|}
\hline \multirow[t]{2}{*}{ No. } & \multirow[t]{2}{*}{ Gene } & \multirow[t]{2}{*}{ Role in the pathogenesis of AD } & \multicolumn{3}{|c|}{$\begin{array}{l}\text { Expression of Genes } \\
\text { (up/down) }\end{array}$} \\
\hline & & & $\begin{array}{l}\mathrm{CuR}+\mathrm{A} \beta \\
\text { vs. } \mathrm{AB}\end{array}$ & $\begin{array}{l}\text { Pip }+A \beta \\
\text { vs. } A B\end{array}$ & $\begin{array}{l}\mathrm{CP}+\mathrm{A} \beta \\
\text { vs. } \mathrm{AB}\end{array}$ \\
\hline 1 & $M M E$ & $\begin{array}{l}\text { Most important A } \beta \text {-degrading enzymes } \\
\text { (Miners et al. 2012) }\end{array}$ & up & up & - \\
\hline 2 & APOE & $\begin{array}{l}A P O E 2 \text { carriers have a protective } \\
\text { effect relative to } A P O E 3 \text { and } A P O E 4 \\
\text { carriers, and therefore the } A P O E 4 \\
\text { protein appears to be 'toxic' and more } \\
\text { likely develop AD (Safieh } \text { et al. } 2019 \text { ) }\end{array}$ & up & up & up \\
\hline 3 & NCSTN & $\begin{array}{l}\text { One of the } \gamma \text {-secretase genes. Mutations } \\
\text { have been reported which linked with } A \beta \\
\text { formation (Pink et al. } 2013 \text { ) }\end{array}$ & up & - & - \\
\hline 4 & $B A D$ & $\begin{array}{c}\text { Increased expression was observed in } \\
\text { AD (Kitamura et al. 1998, Ribarič and } \\
\text { Ribarič 2019) }\end{array}$ & up & - & - \\
\hline 5 & TNFRSF $1 A$ & $\begin{array}{l}\text { Regulation of APP processing; genetic } \\
\text { deletion of the TNF receptor gene } \\
\text { TNFRSF } 1 A \text { in the APP } 23 \text { transgenic } \\
\text { mouse model reduced both the number of } \\
\text { amyloid plaques and the cognitive } \\
\text { deficits in these mice (He et al. 2007, } \\
\text { McAlpine and Tansey 2008) }\end{array}$ & up & - & - \\
\hline 6 & $F A D D$ & $\begin{array}{c}\text { Cortical FADD was lower in subjects } \\
\text { with dementia and lower FADD was } \\
\text { associated with a greater load of } \\
\text { amyloid- } \beta \text { pathology (Ramos-Miguel } \text { et } \\
\text { al. } 2017)\end{array}$ & up & up & up \\
\hline 7 & $L R P 1$ & $\begin{array}{l}\text { LRP1 is an important mediator for the } \\
\text { rapid removal of } A \beta \text { from brain via } \\
\text { transport across the blood-brain } \\
\text { barrier (BBB) (Storck and Pietrzik } \\
2017)\end{array}$ & up & up & up \\
\hline 8 & CASP8 & $\begin{array}{l}\text { Involved in amyloid processing (Rehker } \\
\text { et al. 2017) }\end{array}$ & up & - & - \\
\hline 9 & $P L C B 3$ & $\begin{array}{l}\text { Plays an important role in initiating } \\
\text { receptor-mediated signal transduction } \\
\text { (Lagercrantz et al. 1995). Limited } \\
\text { finding in Alzheimer. }\end{array}$ & up & up & up \\
\hline 10 & CAPN1 & $\begin{array}{l}\text { Upregulation of calpain activation in the } \\
\text { brain of } A D \text { activates CDK } 5 \text {, activates } \\
\text { BACE1,therefore increase } A \beta 40 \text { and } \\
A \beta 42 \text { production in transgenic mice }\end{array}$ & up & - & - \\
\hline
\end{tabular}




\begin{tabular}{|c|c|c|c|c|c|}
\hline & & (Wen et al. 2008) & & & \\
\hline 11 & TP53 & $\begin{array}{c}\text { The increase in the level of } \mathrm{p} 53 \text { has been } \\
\text { detected in the brain tissue of AD } \\
\text { patients (Sajan et al. 2007) }\end{array}$ & up & down & - \\
\hline 12 & $P L C B 4$ & $\begin{array}{l}\text { Plays an important role in initiating } \\
\text { receptor-mediated signal transduction } \\
\text { (Lagercrantz et al. 1995). Limited } \\
\text { literatures in Alzheimer. }\end{array}$ & down & down & down \\
\hline 13 & GNAQ & $\begin{array}{l}\text { The expression level of Gnaq in SAMP8 } \\
\text { mouse forebrain cortex was significantly } \\
\text { decreased with age, alluding to the } \\
\text { possibility that Gnaq expression may be } \\
\text { closely associated with brain aging (Chen } \\
\text { et al. 2010) }\end{array}$ & down & - & - \\
\hline 14 & GRIN2A & $\begin{array}{l}\text { One of the NMDAR subunit gene. A } \\
\text { missense mutation in the coding } \\
\text { regions of the GRIN2B was found only } \\
\text { in the brains of AD patients (Andreoli } \\
\text { et al. 2014) while GRIN2A mutation of } \\
\text { substitution p.N615K is found in a girl } \\
\text { with early-onset epileptic } \\
\text { encephalopathy (Endele et al. } 2010 \text { ). }\end{array}$ & down & down & down \\
\hline 15 & ITPRI & $\begin{array}{l}\text { Involve in calcium signaling pathway. } \\
\text { Mutations in this gene cause } \\
\text { spinocerebellar ataxia (Hisatsune and } \\
\text { Mikoshiba 2017) }\end{array}$ & down & - & - \\
\hline 16 & $G S K 3 B$ & $\begin{array}{l}\text { GSK3 activity and/or protein levels are } \\
\text { increased in afflicted individuals with } \\
\text { AD (Hooper } \text { et al. 2008) }\end{array}$ & down & - & - \\
\hline 17 & PSEN1 & $\begin{array}{l}\text { Presenilin } 1 \text { (PSEN1) encodes the } \\
\text { catalytic subunit of } \gamma \text {-secretase, and } \\
\text { PSEN1 mutations are the most common } \\
\text { cause of early onset familial Alzheimer's } \\
\text { disease (FAD) (Sproul et al. 2014) }\end{array}$ & - & up & - \\
\hline 18 & PPP3CC & $\begin{array}{l}\text { Referred to as calcineurin. For memory- } \\
\text { associated disorder, AD, average levels } \\
\text { of calcineurin expression and calcineurin } \\
\text { activity for AD brains are decreased } \\
\text { (Gong et al. 2006) }\end{array}$ & - & up & - \\
\hline 19 & CASP9 & $\begin{array}{l}\text { This gene has been reported to involve in } \\
\text { neuroinflammation and apoptosis leading } \\
\text { to the onset of AD (Abid et al. 2019). }\end{array}$ & - & up & - \\
\hline 20 & ERN1 & $\begin{array}{l}\text { IRE1 impairment completely restored } \\
\text { AD mice's learning and memory } \\
\text { capacity, combined with enhanced } \\
\text { synaptic function and increased long- }\end{array}$ & - & up & - \\
\hline
\end{tabular}




\begin{tabular}{|c|c|c|c|c|c|}
\hline & & $\begin{array}{l}\text { term potential (LTP) (Duran-Aniotz et al. } \\
\text { 2017). }\end{array}$ & & & \\
\hline 21 & $I D E$ & $\begin{array}{l}\text { Previously reported as a late-onset AD } \\
\text { gene based on its potential to degrade } \\
\text { amyloid } \beta \text {-protein (Vepsäläinen et al. } \\
\text { 2007) }\end{array}$ & - & down & - \\
\hline 22 & $A P H 1 A$ & $\begin{array}{c}\text { Encodes a gamma secretase complex } \\
\text { component. Polymorphisms were } \\
\text { associated with an increased risk of } \\
\text { developing sporadic Alzheimer's disease } \\
\text { in a promoter region of this gene (Wang } \\
\text { and Jia 2009). }\end{array}$ & - & down & - \\
\hline 23 & $C Y C S$ & $\begin{array}{c}\text { Involve in mitochondrial dysfunction as } \\
\text { well as inflammation and apoptosis } \\
\text { linked to AD (Kim et al. 2018). }\end{array}$ & - & down & - \\
\hline 24 & CALM2 & $\begin{array}{l}\text { Down-expression of this gene from AD } \\
\text { contribution was reported in the } \\
\text { cerebellum of autistic patients (Zeidán- } \\
\text { Chuliá et al. 2014) }\end{array}$ & - & - & down \\
\hline 25 & $C A S P 3$ & $\begin{array}{l}\text { This gene has been reported to involve in } \\
\text { neuroinflammation and apoptosis leading } \\
\text { to the onset of AD (Abid et al. 2019). }\end{array}$ & - & - & down \\
\hline
\end{tabular}

2 Note: Six genes were shared among the three comparisons identified as APOE, FADD, LRP1,

3 PLCB3, PLCB4 and GRIN2A (shown in bold)

4

5

6

7

8 
Figure 1

Optimized amyloid-beta fibril preparation (Adapted with slight modifications from Caballero et al. 2016).

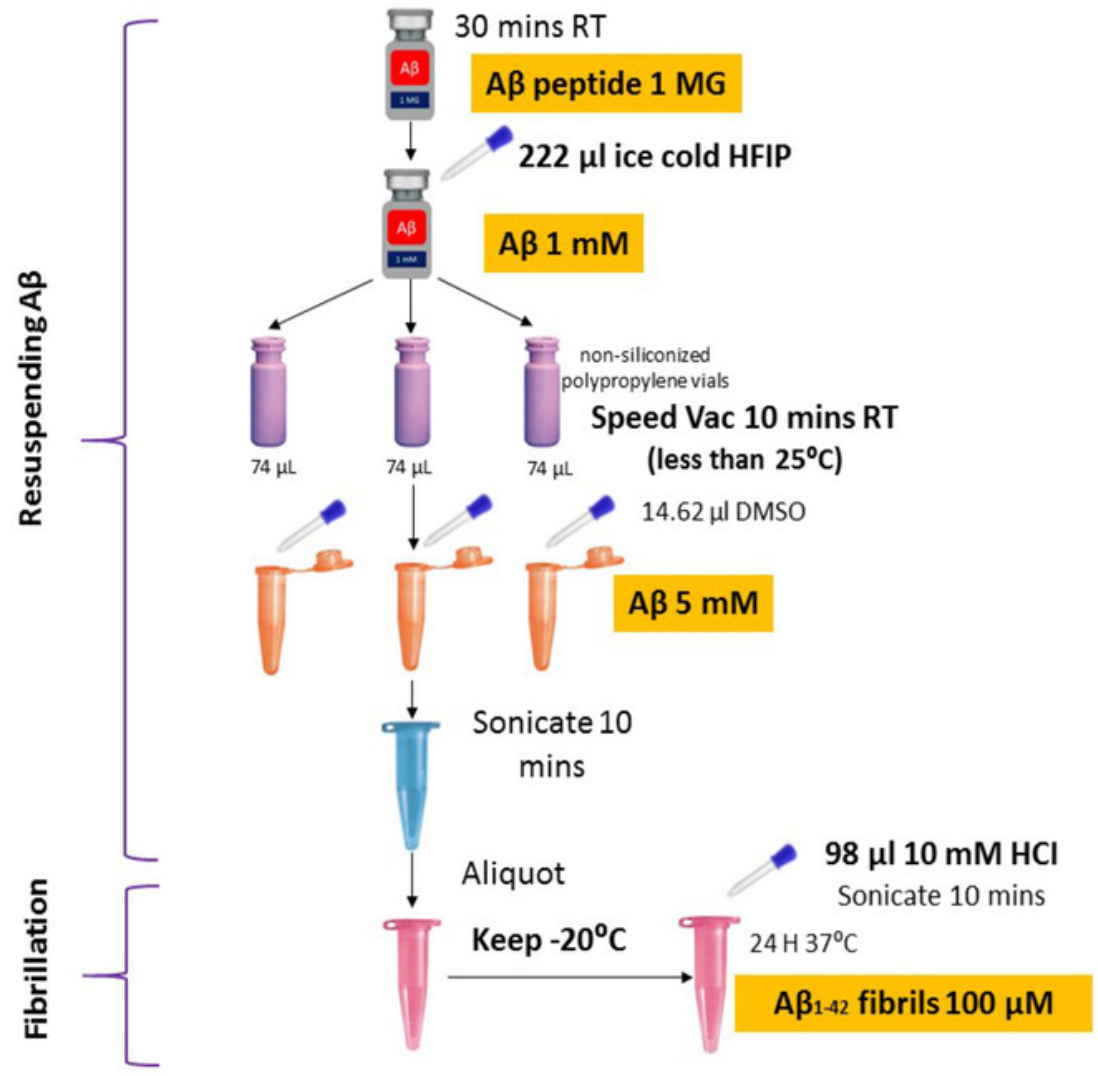




\section{Figure 2}

Cell images of $A \beta$ in SH-SY5Y cells under A) \& B) Brightfield and Fluoresence Microscopy and C) \& D) Immunofluorescence Microscopy under 20X magnification.
A) untreated SH-SY5Y cells and B) SH-SY5Y cells treated using Thioflavin T (ThT) and C)
negative control and $D$ ) treated cells (primary Ab: 1:200; secondary Ab: 1:1000 dilution). The stains 4',6-diamidino-2-phenylindole (DAPI) was used to stain the nuclei (blue) and Fluorescein isothiocyanate (FITC) was used to stain the amyloid beta peptides (A $\beta$ ) (green). Scale bar $=50 \mu \mathrm{m}$. 
A)

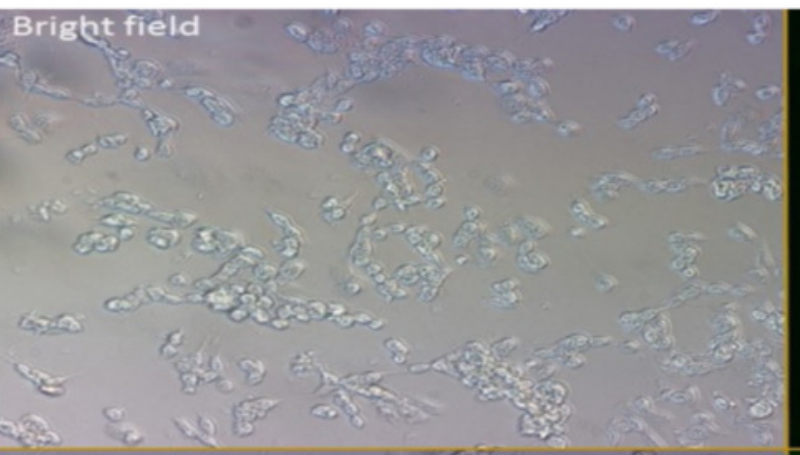

B)

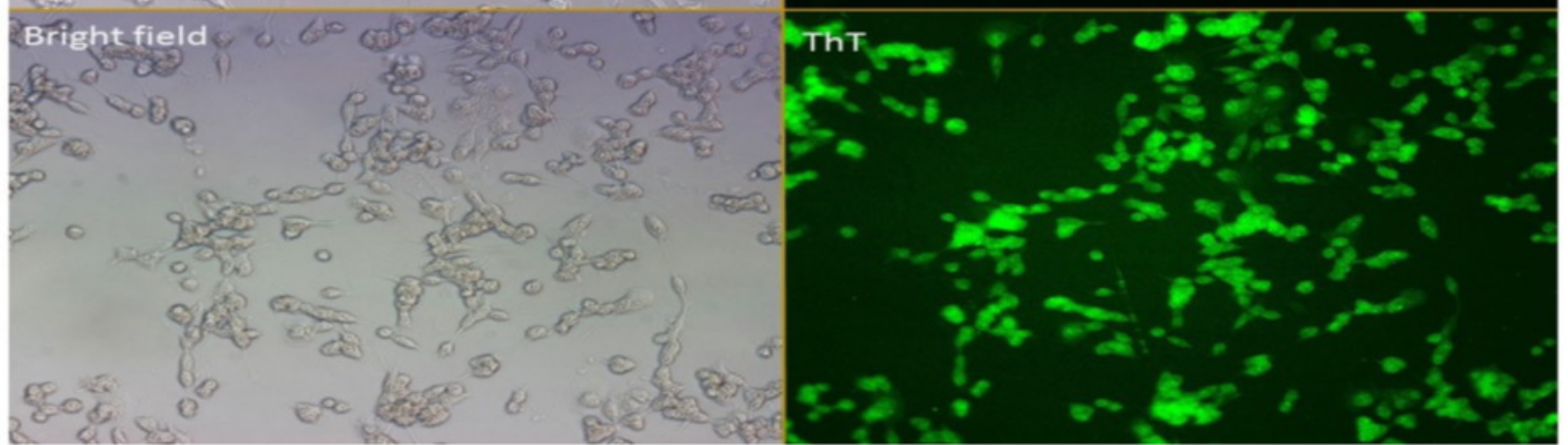

C)

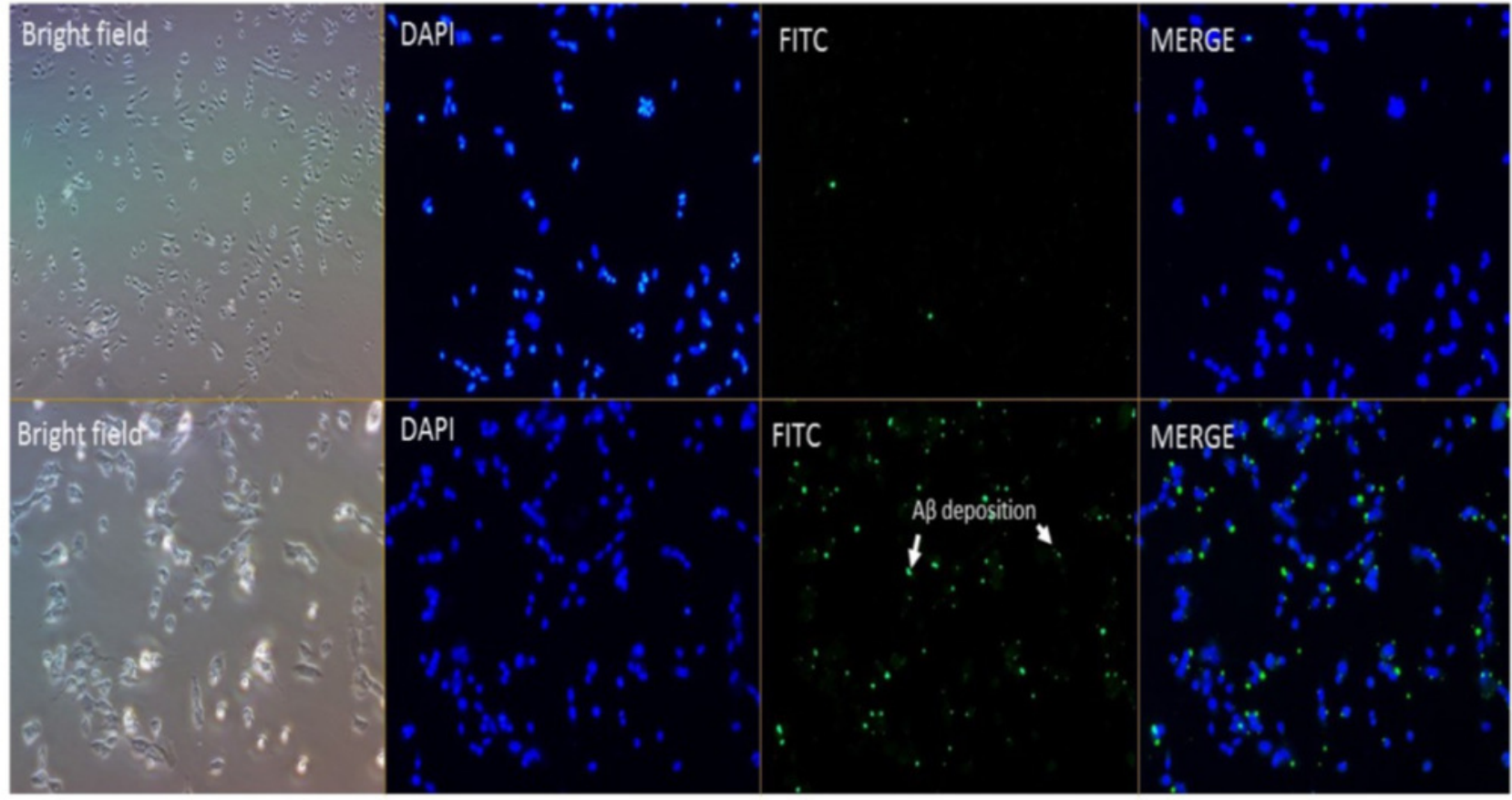




\section{Figure 3}

Principal Component Analysis Mapping of SH-SY5Y cells under various conditions. A-Blue dots represent $A \beta$ Control, $B-$ Red dots represent $C u R+A \beta, C-G r e e n$ dots represent Pip $+A \beta$ and $D$-Purple dots represent $C P+A \beta$. All samples with no overlapped distr

C: Control (no treatment); CuR: Curcumin; Pip: Piperine and CP: Combined curcumin and piperine.

PCA Mapping $91.1 \%$ (CEL)

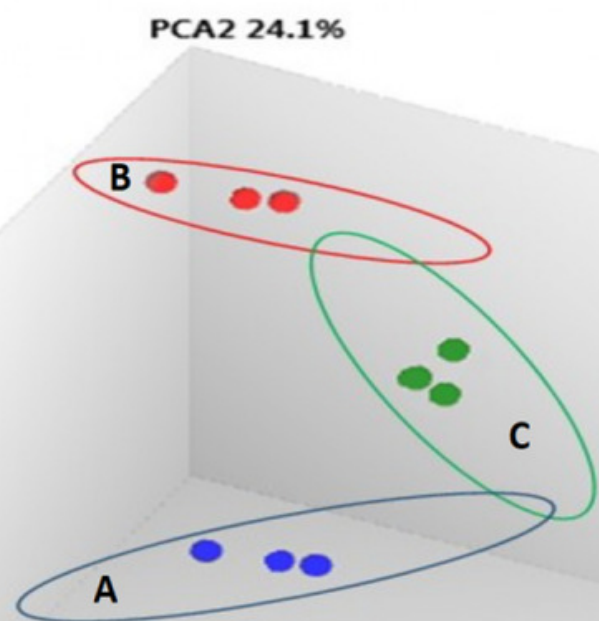

\section{Condition}

$A \square \mathrm{AB}-\mathrm{C}$

$B \square \mathrm{CuR}+\mathrm{AB}$

$C$ Pip $+A B$

$D \square C P+A B$

PCA1 63.1\% 
Figure 4

Hierarchical Clustering of three different groups reveals clear separation of samples. $(A)$ $[C u R+A \beta]$ vs. $A \beta,(B)[P i p+A \beta]$ vs. $A \beta$ and $(C)[C P+A \beta]$ vs. $A \beta$. (ANOVA: $P<0.05$, $\log 2>6.64$, a fold change $\geq 2$ or $\leq-2$ ) (CuR: Curcumin; Pip: Piperine and CP: Combi

(A) $[C u R+A \beta]$ vs. $A \beta,(B)[P i p+A \beta]$ vs. $A \beta$ and (C) $[C P+A \beta]$ vs. A $\beta$. (ANOVA: $P<0.05$, $\log 2>6.64$, a fold change $\geq 2$ or $\leq-2$ ) ( AB: Amyloid beta; Curcumin; Pip: Piperine and CP: Combined curcumin and piperine).

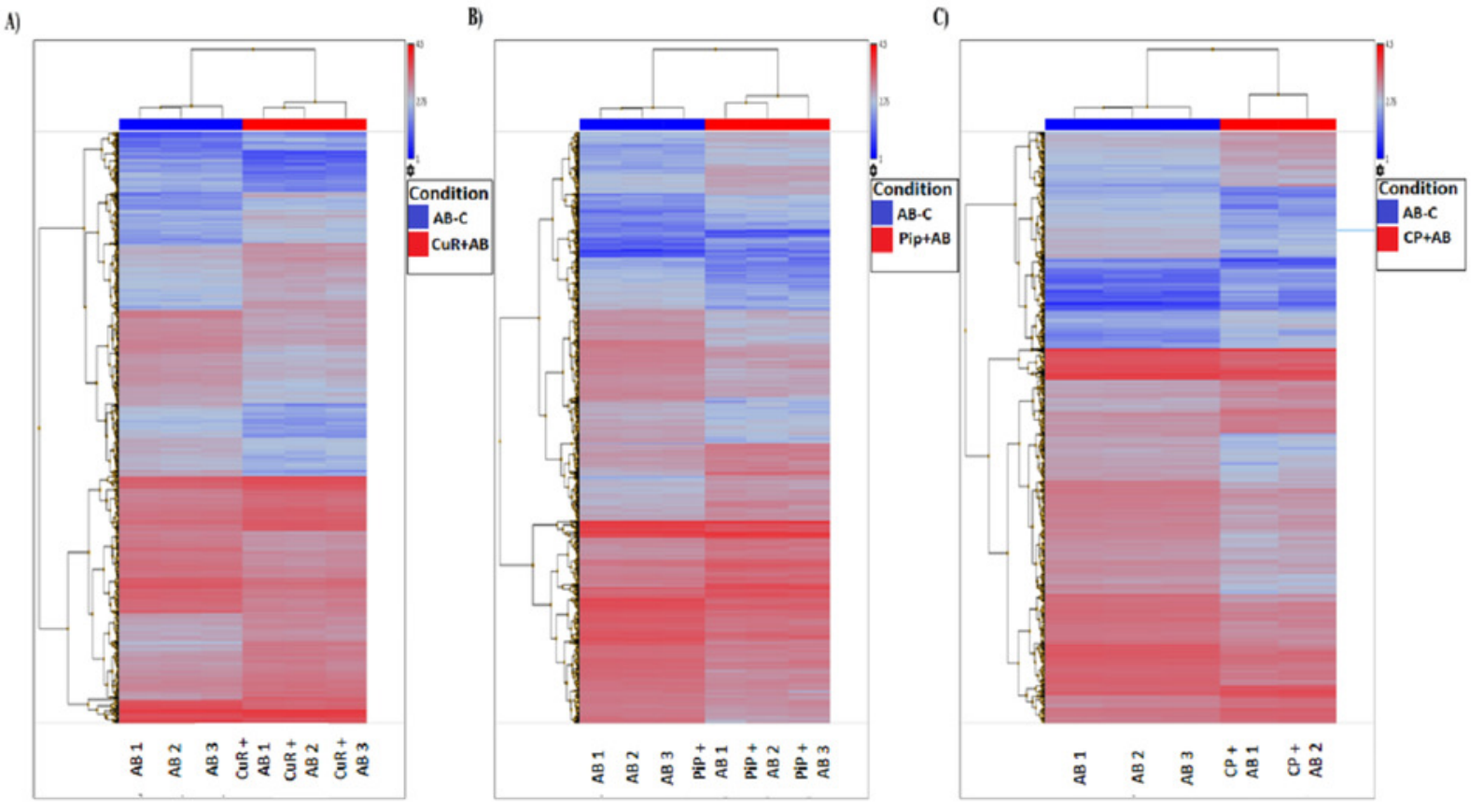




\section{Figure 5}

Figure 5. Venn diagram showing overlapping genes with significant gene expression in each comparison.

Total number of up- and downregulated genes in each group are shown in parentheses (CuR: Curcumin; Pip: Piperine and CP: Combined curcumin and piperine). (ANOVA: P<0.05, log2>6.64, a fold change $\geq 2$ or $\leq-2$ ).

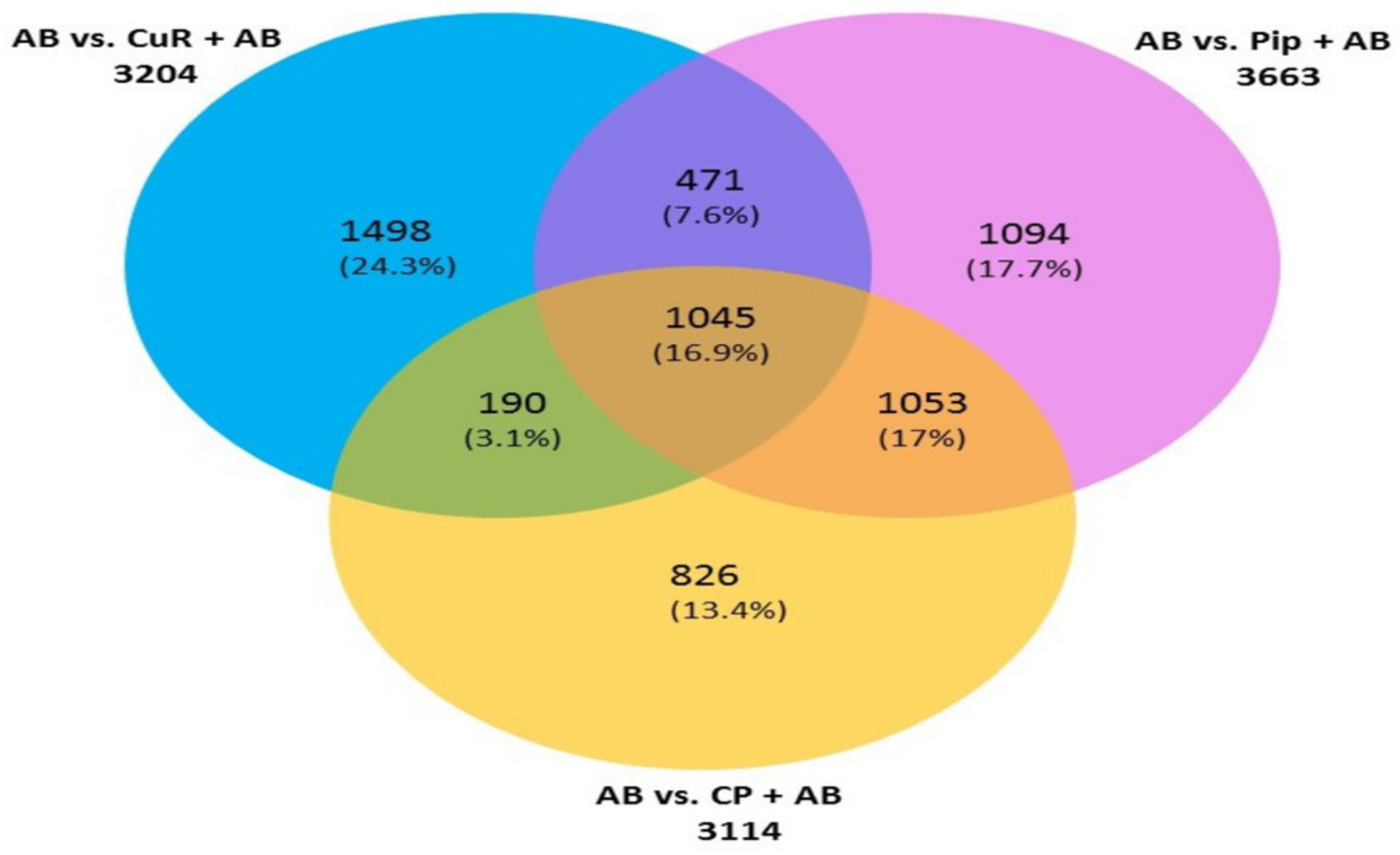


Figure 6

Figure 6. Protein-protein interaction network of differentially expressed genes (DEGs) by using Network Analyst Software 3.0.

A) on the top 20 most significant DEG, B) on top 25 most significantly DEG and C) on top 8 most significantly DEG. The color represents the degree of the nodes. Red nodes are most important interactions, followed by pink nodes and finally purple nodes. Nodes in blue represent those proteins interacting in cancer pathways.

A)

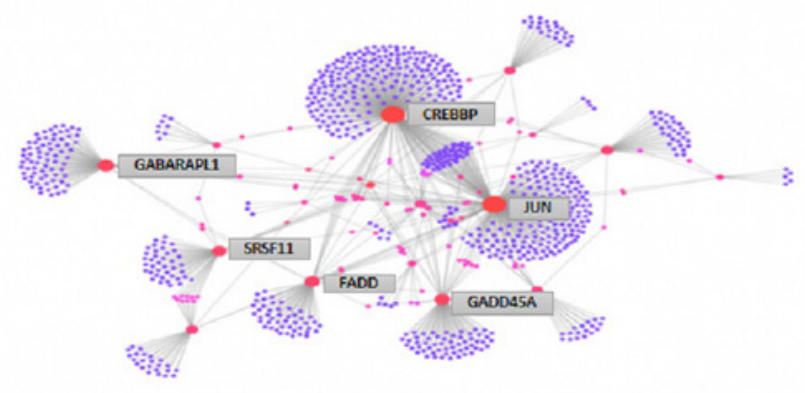

C)
B)

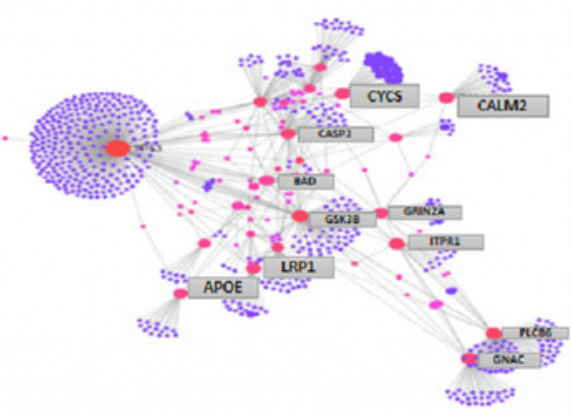

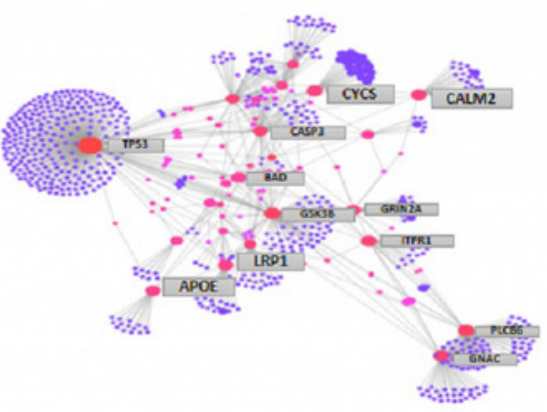


Figure 7

Figure 7. Validation of selected differentially expressed gene candidates by qPCR in SHSY5Y cells.

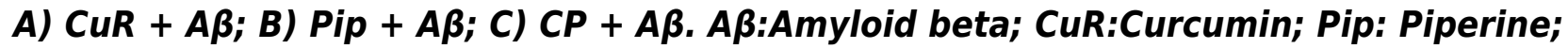
CP:Curcumin-Piperine.
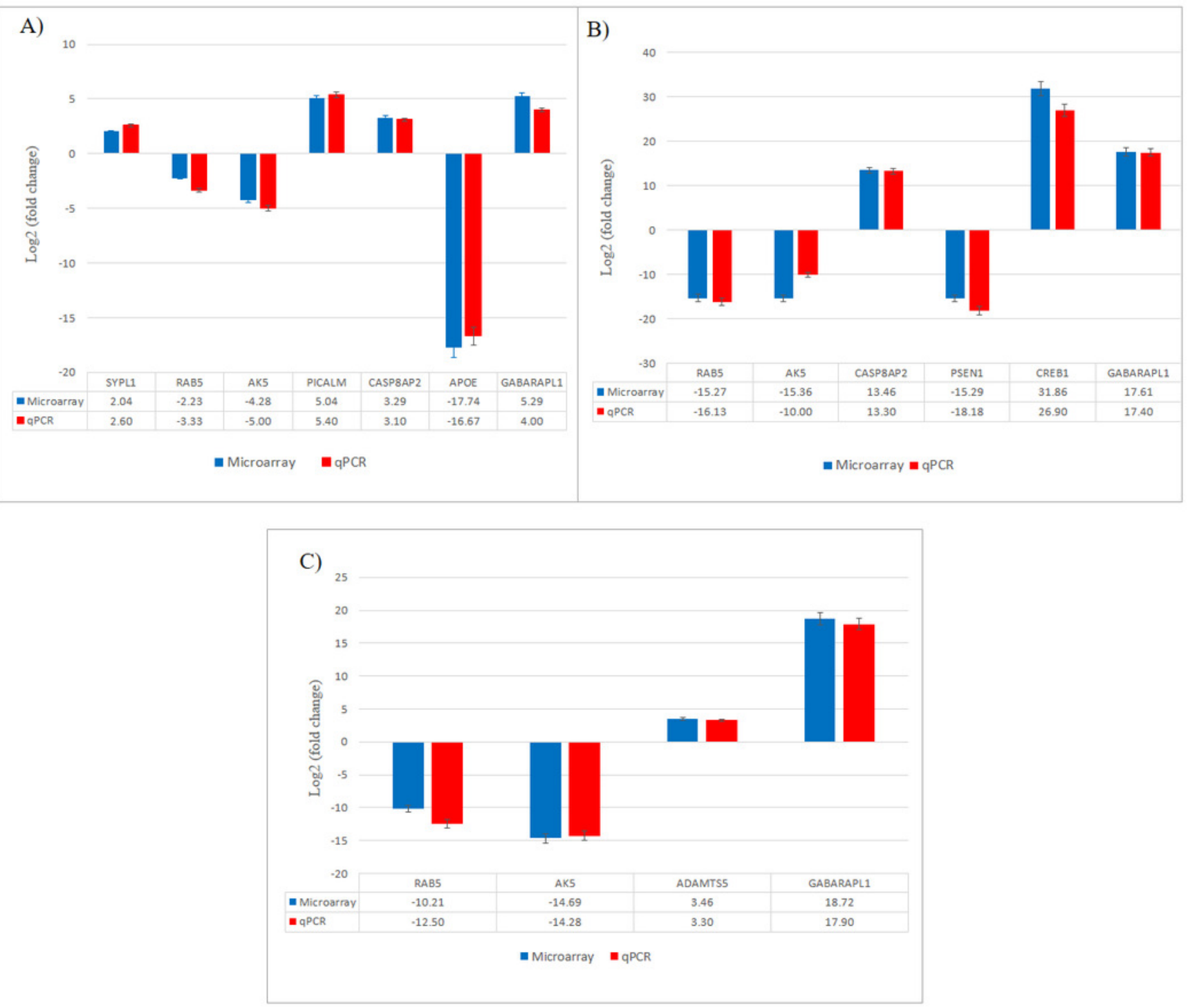
Figure 8

Figure 8. $A \beta$ extrinsic pathway and the genes observed in array analysis. The genes shown were modulated either by singular or combined treatment of curcumin and piperine. (CuR: Curcumin; Pip: Piperine and CP: Combined curcumin and piperine).

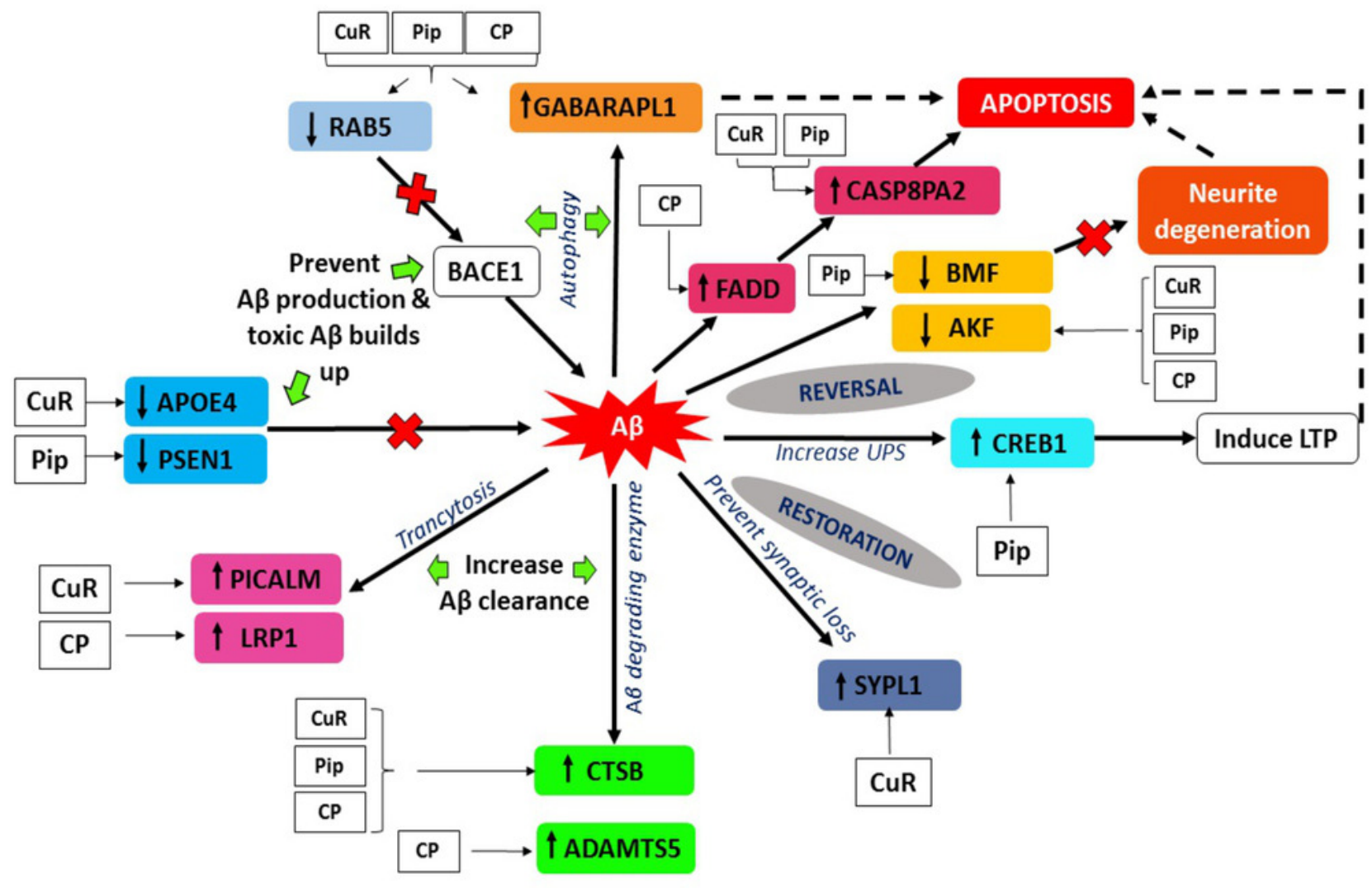




\section{Figure 9}

Figure 9. Aß-dependent role of PICALM in AD. (Adapted from Xu, Tan \& Yu, 2015).

PICALM can promote not only the formation of $A \beta$ peptide through the endocytosis system, but also its clearance through the activation of autophagic APP-CTF processes and the facilitation of extracellular $A \beta$ to cross the blood-brain barrier (BBB) vascular endothelial cells. (CCVS: clathrin-coated vesicles; LC3: light chain 3).

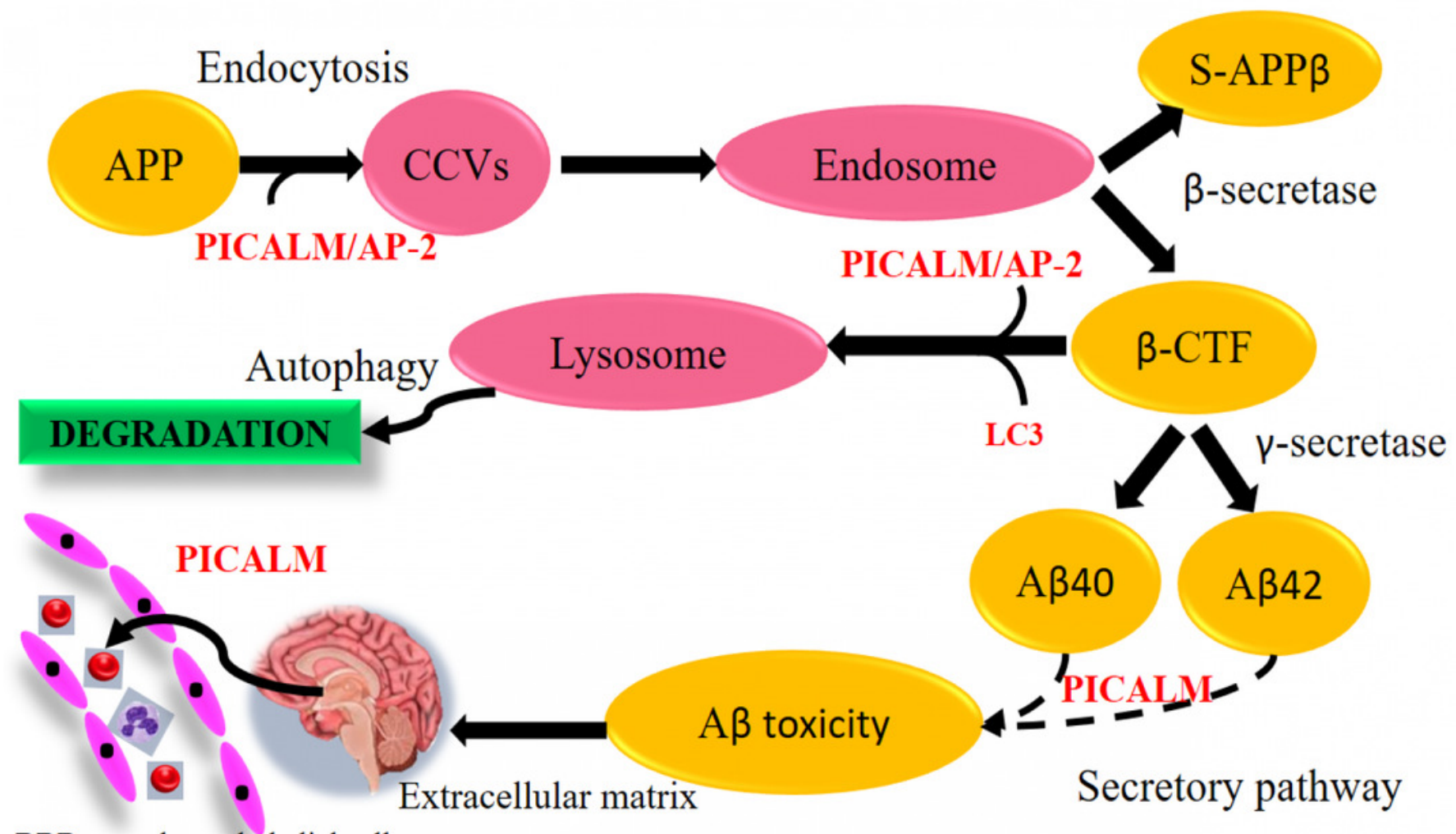

BBB-vascular endothelial cell 